\title{
The Six Thinking Hats and Their Effect on Improving the Skill of Lesson Planning and attitudes of Students in Teaching Practicum within the Faculty of Physical Education for Men
}

\section{Dr. Walid Salah Aly EIMesawy ${ }^{(*)}$ Dr. Ahmed Mohamed Abd EL-Monem Allam ${ }^{(*)}$}

should stress on skills such as planning, implementation, and evaluation to contribute in upgrading teacher's teaching performance (215:7).

Zaineb, Ghada Galal (2008), Brown $(2005,156)$ and Salem (1998) agree on that the most necessary and important teaching skills for a student teacher or basic stages which teacher must observe for success in teaching profession and field training include:(planning and lessons preparation- Skill implementation- follow-up and evaluation).

In this regard, Kamal (1997) mentions that planning, in general, is a method that takes scientific tools for achieving certain future goals. It is one of the most important stages in teaching process being carried out by the teacher before facing learners in the class. The importance of lesson planning comes because of lesson planning in advance reflected directly or indirectly on teacher's behavior in his class and in front of his learners. It is a big mistake from any teacher to depend on his memory and neglect lessons' preparation, where every lesson no matter how simple it is requires from the teacher to make a teaching plan.

Shehata (1998) adds that lesson planning makes the teacher thinks and manages what will be done. Proper planning requires from the teacher to have knowledge about students' characteristics, needs and abilities; so that she/he can adapt teaching with these variables. Teacher should be able to understand learning objectives, and analysis course content according to course's aims and determine the best sequence to present each lesson, and from all these steps, the lesson plan comes out to be used as a guide during implementation.

Gaber $(1998,233)$ argues that successful learning is usually a result of noticeable amount of pre-teaching planning. Planning makes it possible to distribute time and build productive learning environment. It helps to rapid advances in teaching process; therefore teacher should evaluate what has been learned; then use this information in subsequent lessons planning. Planning is an essential part of effective teaching.

Bailey $(2003,23)$ adds that teaching involves a set of challenges; and effective planning may be one of the best tools that teacher may use in facing these challenges. Planning process may consume some time, but this is usually beneficial, moreover planning is one teacher's work which remains under his direct control.

Zainb and Ghada Galal $(2008,119)$ argue that the skill of planning lesson is an essential and important stage of teaching and learning; through which lesson acquires practical nature. It includes arrange the facts of the lesson in logic order which commensurate with learners' capabilities, characteristics and needs, in addition to setting goals, arranging thoughts, commitment to time plane for content distribution and preparing daily lessons to be implemented in light of the general plan.

The Six Thinking Hats is one of the modern strategies that used in Physical Education as one of educational studies in teaching and learning field, it improves cognitive aspects in a manner which is based on higher mental processes, through its styles and thinking methods either in regular linear or non-linear methods. Starting from using the six-hats, providing information, knowledge and concepts and terminology to students to help them for on neutral thinking to give an overall picture and logical thinking about these information and knowledge in an orderly manner acquired from interaction and experience between teacher and students. In that situation, Al-Gyoshi $(2001,49)$ quotes from Bono that Six Thinking Hats purposes in:

\footnotetext{
${ }^{(*)}$ Lecturer, department of school sports, faculty of physical education for men, Alexandria university.

${ }^{(* *)}$ Lecturer, department of physical education foundations, faculty of physical education for men, Alexandria university.
} 
(defining roles - influence moods aspects - draw attention - development of game rules and appropriateness for other's responses and inquiries).

Using six hats strategy in teaching can achieve successful education objectives through:

1- Providing varied activities starting from information, facts and vary according each hat's usage requirements

2- This strategy allows student teacher to carry out surveys to collect information and thinking processes.

3- Allowing student to participate in all stages of the lesson, starting from searching for information and even to providing guidance and organization.

4- It is used in lesson presentation, and can also be used in learning evaluation. (http://www.sandroses.com/abbs/t142411), (http://www.sandroses.com/abbs/t142411)

The Following is a simple presentation of six thinking hats' types:

1- White Hat (neutral thinking): it's a neutral and objective hat, who wears this hat acts as a researcher for information and facts, asks questions in order to obtain information. White color (absence of colors) symbolizes the neutrality; white hat thinking is based on objectivity, neutrality, facts and figures. Teacher can use several methods to present facts, such as: lecture - discussion - questions and answers - survey ... etc.), there is no specific one way to produce facts, the important in using white hat is to introduce students teacher to the facts $(2001,53, .83-84)$

2- Red Hat (emotions and feelings): it presents feelings and emotions, which is contrary to white hat. Student teacher is be allowed to express his feelings, even without having sufficient information and facts (Teaima,1999,85,115-116)

Pal (2004) adds that red hat is a hat based on what lies in depth from emotions and feelings, as well as intuition; it reveals feelings, emotions, and moral and humanitarian aspects on the problem (19:19).

3- Black Hat (negative thinking): it searches for defects and defaults (Al-Gyoshi,2001, 117 153 154)

4- Yellow Hat (positive thinking): it searches for Positives and benefits (Teaima, 155183 184)

Pal, $(2004,19)$ adds that it is the hat of optimism and thinking about work and benefits, and it finds out some of useful results, suggestions and economic feasibility. The person who wears the yellow hat can ask: What are the benefits? Who is the beneficiary? What are the positives aspects?

5- Green Hat (creative thinking): it is tries to solve problems in unusual ways and looking at alternatives; not just taking more clear way or as they say (Necessity is the mother of invention) (Al-Gyoshi, 2001, 185, 227-228).

6- Blue Hat (comprehensive thinking), it presents control, management, implementation and organization. Blue color symbolizes the comprehensive control as the similarity of the sky that covers everything. Teacher declares that the blue hat is an implementation hat, and requests from student teacher to develop implementation plans in light of what have been done in previous hats from information, feelings, positives and negatives things, and suggestions. They determine implementation steps such as: formation of committees to work, communicate with other institutions, tools collection and preparation. (Teaima, 1999. 229, 261-262)

Hecerian (2004) indicates that the blue hat symbolizes the comprehensive thinking. It is general view thinking. They chose the blue color because it suggests briefing and strength as the sea. So you will think how and direct the necessary thinking to get the best result. Blue hat is making of work schedule.

\section{Research problem:}

Practicum Course within the Faculty of Physical Education for Men which is determined by the internal regulations of Faculty of Physical Education for men in Alexandria University as 
a general course includes practical teaching hours only, and there is no hours specified for theoretical lectures, even that this course, as its description, includes theoretical and practical topics. This course includes (planning, implementation and evaluation), but staff who teach this course give attention to implementation and evaluation and ignore cognitive (planning) part. Due to this course's importance, especially for faculty's students as a general course, and later for students who will work in school sports specialization, this course is required to be reviewed and studied to verify its effectiveness in achieving its objectives. One of the researchers throw his teaching of this course, he was be able to conduct a pilot study using standardized observation (appendix 1). This study targeted teaching methods, styles, aids, modern techniques, students' behaviors, performances and their responses to the course. By analyzing the items if this observation, he found some shortcomings represented in lack of diversification of teaching methods and styles, lack of teaching and technological aids in both theory and application sides, and students are not involved in implementation of syllabus. Also from key points found by both researchers that there is planning for some lessons, but it is not unified in schematic form as well as there are lack in setting goals, selecting topics, skills, evaluation methods within the lesson, identifying the means and tools used in the lessons, and the method of writing exercises within the physical preparation part. In this regard also, the researchers measured the students' teaching skills and noted severe weakness in planning, implementation, and evaluation skills, students even cannot complete some teaching skills. The researchers traced students' result of Practicum Field Course (appendix 2) and he found out that students' success percentage was lower than the expected level in this syllabus, ranged between "[pass and good", two students only got excellent Grade, and most of the students got pass grade. Both researchers return this to lower allotted time to teach this Course, as well as traditional teaching and learning methods followed in teaching this syllabus.

\section{Study Importance}

1- Shedding light on one of teaching strategies (Six Thinking-Hats) and trying to practically apply it on Field Practicum syllabus.

2- Helping students with low and mid-level to access to good performance level of planning Physical Education lessons.

3- Pushing students' attitudes towards Six Thinking-Hats instead of normal thinking in solving problems and educational situations.

\section{Study Objectives}

This study aims to identify the effect of Six Thinking-Hats on Improving Lesson

Planning Skill and attitudes on the students of Field Practicum course within the Faculty of Physical Education for Men.

\section{Research Hypotheses:}

1. There are statistically significant differences between post measurements for control and experimental group of lesson planning skill in favor of experimental group.

2. There are statistically significant differences between pre and post measurements for experimental group of lesson planning skill in favor of post measurement.

3. There are statistically significant differences between pre and post measurements for control group of lesson planning skill in favor of post measurement.

\section{Research Terms: \\ Six Thinking-Hats:}

A set of procedures and practices followed by teacher with students in order to encourage organized linear thinking according to lesson planning strategies on scientific basis for lesson preparation and organization of good learning situations. (Procedural)

\section{Lesson Planning Skill:}

A series of integrated and interactive actions which is carried by teacher on multiple timing levels to identify and conceptualize for all lesson's aspects from the beginning to the end. Also teacher needs to develop solutions and suggestions for matters that may hinder achieving the selected and worded objective (Procedural). 


\section{Internal Field Practicum:}

It is the period when the student of the second year applies - inside the faculty - a group of teaching experiences, knowledge and skills acquired during his preparation period under accurate scientific supervision; aiming to prepare the student for external field training. $(15: 6)$

\section{Previous studies:}

1- Al-Aweida (2011) titled "Teaching Strategy that based on Six Thinking Hats Program". The research aimed at developing the creative education skills of students in areas of: Planning, implementation, and evaluation and their attitudes towards it. She used the experimental approach with a single group of (25) students from those attending General Diploma in Arabic language. Research's tools are subjected on them, before and after the experiment. Statistical processes revealed the following results: there were statistically significant differences between pre and post measurement in favor of post measurement. There were statistically significant differences between pre and post measurement in lesson planning, implementation and evaluation skills' observation card in favor of post measurement.

2- Al Shaya, and Al-Oqil (2009) (12) titled " The effect of using the Six Thinking Hats in teaching science on development of creative thinking and verbal classroom interaction for students of sixth grade in Riyadh ". This study aimed at finding out the effect of using Six Thinking Hats in teaching science on developing creative thinking, and verbal classroom interaction for sixth grade students in Riyadh. The experimental approach was used with two groups (experimental and control) each of both contained (30) students, Torrance scale (form B) was used for its suitability for Saudi environment to measure creative thinking. Flanders tool was used to identify verbal classroom interaction between teacher and students. The results showed that there were no statistically significant differences between respondents in creative thinking skills (fluency, flexibility, originality, and details) separately, and in total creative thinking test, also results revealed the effectiveness of six hats in improving verbal classroom interaction between the teacher and the students.

\section{Research Procedures:}

\section{I- Methodology}

Both researchers used the descriptive survey approach in designing academic lectures using Six Thinking Hats Strategy, Lesson planning observation card, and attitudes scale. Experimental approach with two groups (control and experimental) was also used due to its suitability to the research's nature.

\section{II-Research domains:}

Human domain: consists of the students of the second year in the Faculty of Physical Education for Men- Alexandria University, experts, and specialists in curricula, physical education, teaching methods and psychology.

Time domain: The academic year (2013/2014).

Spatial domain: - Faculty of Physical Education for Men, Alexandria University.

\section{III- Study Community and Sample:}

Study's community consists from the students of the second year from the Faculty of Physical Education for Men, Alexandria University, staff members of departments of curricula and teaching methods and psychology professors in faculties of education and physical education in 2013/2014 academic year. The study was conducted on a random sample of (70) students, and (7) staff members specialized in Curricula, teaching methods and psychology (appendix 3)

- Random sample of second year students, school sports department in Faculty of Physical Education for Men, Alexandria University.

Table (1) sample size and its proportion to original society

\begin{tabular}{l|l|l|l}
\hline \hline No. & \multicolumn{1}{|c|}{ Description } & \multicolumn{1}{c}{ Number } & \multicolumn{1}{c}{ percentage } \\
\hline \hline 1 & Students' original society & 457 & $100 \%$ \\
\hline 2 & Experimental group & 35 & $8 \%$ \\
\hline \hline
\end{tabular}




\begin{tabular}{l|l|l|l}
\hline \hline 3 & Control group & 35 & $8 \%$ \\
\hline 4 & Main study sample & 70 & $15 \%$ \\
\hline 5 & Pilot study sample & 23 & $7 \%$ \\
\hline 6 & Total study sample & 93 & $20 \%$ \\
\hline 7 & Experts & 7 & $100 \%$ \\
\hline
\end{tabular}

IV - Data collection Tools:

- Expert's Opinion Questionnaire form was in:

1- Designing theoretical lectures based on Six Thinking Hats strategy. (Designed by both researchers) (appendix 4)

2- Observation Card for lesson planning skill under study. (Designed by both researchers) (appendix 5)

3- Attitudes scale under study. (Designed by both researchers) (appendix 6)

$\mathrm{V}$ - Study Implementation Procedures:

\section{Pilot Studies:}

Ensuring scientific standards for forms and tests under study by ensuring:

- Validity (forms were presented on experts in areas of specialization (Experts validity), internal consistency validity.

- Reliability (applying these forms / re-applying them).

- Objectivity (applying the form and judging it through observation the sample by experts including one of the researchers within experts group to be able to observe lesson planning skill for students in pre and post measurements).

\section{Pre measurements:}

Observation card of Lesson planning skill for ensuring groups homogeneity

\section{Main study:}

Main study was implemented using Six Thinking Hats strategy for two consecutive months (two hours a week) in the period between (March $3^{\text {rd }}, 2014$ and May $15^{\text {th }}, 2015$ )

\section{Post measurements:}

Observation card of Lesson planning skill- attitudes scale

\section{- Designing Research Tools:}

A- Designing of observation card of Lesson planning skill is according to the following steps:

1. Determining the objectives of the card which should be in line with the research's objectives 2. Identifying the appropriate aspects and phrases of the card 3- Developing and wording card items 4- Developing appropriate instruction 5- Determining the time of the test 6- the card in its initial form (before scientific standards) 7 - the card in its final form (after scientific standards).

- Statistical description for experimental and control groups using the observation card of the Lesson planning skill

Table (2)

Statistical description for the experimental and control groups' variables in the observation card of the Lesson planning skill before experiment implementation

$\mathrm{n}($ experimental $=35$, control $=35$, total $=70)$

\begin{tabular}{|c|c|c|c|c|c|c|c|c|}
\hline variables & groups & $\begin{array}{l}\text { Number } \\
(\mathrm{n})\end{array}$ & $\begin{array}{l}\text { Measurement } \\
\text { unit }\end{array}$ & mean & $\begin{array}{l}\text { Standard } \\
\text { deviation }\end{array}$ & Minimum & Maximum & $\begin{array}{l}\text { Skewness } \\
\text { coefficient }\end{array}$ \\
\hline \multirow{2}{*}{$\begin{array}{l}\text { observation card of } \\
\text { the Lesson planning } \\
\text { skill }\end{array}$} & $\begin{array}{l}\text { Experimental } \\
\text { group }\end{array}$ & 35 & mark & 33.23 & 3.94 & 27.00 & 39.00 & -0.21 \\
\hline & Control group & 35 & mark & 29.83 & 3.91 & 24.00 & 40.00 & 0.91 \\
\hline $\begin{array}{l}\text { Total score of } \\
\text { observation card of } \\
\text { the Lesson planning } \\
\text { skill }\end{array}$ & $\begin{array}{l}\text { observation card } \\
\text { (as a whole) }\end{array}$ & 70 & mark & 31.53 & 4.26 & 24.00 & 40.00 & 0.27 \\
\hline
\end{tabular}

Table (2) results reveal that all skewness coefficients values are close to zero indicating normality of these variables. 
- Homogeneity between groups in lesson planning skill using the observation card:

Table (3)

Significance of differences between experimental and control groups in the observation card of the Lesson planning skill before experiment implementation

\begin{tabular}{c|c|c|c|c|c|c|c}
\hline \multirow{2}{*}{ Statistics } & \multirow{2}{*}{$\begin{array}{c}\text { Measurement } \\
\text { unit }\end{array}$} & \multicolumn{2}{|c|}{$\begin{array}{c}\text { experimental } \\
\text { group } \\
(\mathbf{n = 3 5})\end{array}$} & \multicolumn{2}{|c|}{$\begin{array}{c}\text { control group } \\
(\mathbf{n = 3 5})\end{array}$} & \multirow{2}{*}{$\begin{array}{c}\text { Difference } \\
\text { between } \\
\text { means }\end{array}$} & $\begin{array}{c}\text { (T) } \\
\text { value }\end{array}$ \\
\cline { 3 - 6 } & & Mean & $\begin{array}{c}\text { Standard } \\
\text { deviation }\end{array}$ & Mean & $\begin{array}{c}\text { Standard } \\
\text { deviation }\end{array}$ & & \\
\hline \hline $\begin{array}{c}\text { Lesson planning } \\
\text { skill }\end{array}$ & marks & 33.23 & 3.94 & 29.83 & 3.91 & 3.40 & $\begin{array}{c}3.62 \\
*\end{array}$ \\
\hline \hline
\end{tabular}

* Significant at 0.05 level $(\mathrm{T}$ critical $=2.00)$

Table (3) results reveal a presence of significant differences between experimental and control groups in the observation card of the Lesson planning skill before experiment implementation where $\mathrm{T}$ calculated value (3.62) is greater than $\mathrm{T}$ critical at 0.05 levels, which shows that the two groups are not homogeneous in the observation card of the Lesson planning skill before experiment's implementation. This requires from us to statistically deal at comparison between experimental group and the control groups in the observation card to identify the effect of the proposed program after proposed program implantation by comparing (differences between pre and post measurement) for experimental group and (differences between pre and post measurement) for experimental group and this statistical procedure has been performed due to lack of homogeneity between the control and experimental groups in pre and post measurement.

- Frequency and percentage of experts opinion on the observation card of the Lesson planning skill (appendix 7)

- Validity, reliability and objectivity of lesson planning skill observation card:

1- Validity: researchers have used:

- Internal consistency coefficient. (appendix 8)

- Comparison between highest and lowest quartiles for the observation card of the Lesson planning skill as illustrated by the following table:

Table (4)

Comparison between highest and lowest quartiles for the observation card of the Lesson planning skill

\begin{tabular}{|c|c|c|c|c|c|c|c|c|}
\hline \multirow{2}{*}{ variables } & \multirow{2}{*}{$\begin{array}{l}\text { Measurement } \\
\text { unit }\end{array}$} & \multicolumn{2}{|c|}{$\begin{array}{c}\text { Highest quartile } \\
(n=6)\end{array}$} & \multicolumn{2}{|c|}{$\begin{array}{c}\text { Lowest quartile } \\
(\mathbf{n}=7)\end{array}$} & \multirow{2}{*}{$\begin{array}{c}\text { Difference } \\
\text { between } \\
\text { means }\end{array}$} & \multirow{2}{*}{$\begin{array}{c}(\mathrm{T}) \\
\text { value }\end{array}$} & \multirow{2}{*}{$\begin{array}{l}\text { Validity } \\
\text { coefficient }\end{array}$} \\
\hline & & Mean & $\begin{array}{l}\text { Standard } \\
\text { deviation }\end{array}$ & Mean & $\begin{array}{l}\text { Standard } \\
\text { deviation }\end{array}$ & & & \\
\hline $\begin{array}{c}\text { Lesson planning } \\
\text { skill }\end{array}$ & $\overline{\mathrm{M}_{\mathrm{c}}}$ & 446.33 & 2.25 & 37.29 & 3.04 & 9.05 & $6.00^{*}$ & 0.88 \\
\hline
\end{tabular}

* Significant at 0.05 level $(\mathrm{T}$ critical $=2.20)$

Table (4) results reveal a presence of statistically significant differences between highest and lowest quartiles as $\mathrm{T}$ calculated value (6.00) is greater than the $\mathrm{T}$. critical value at 0.05 levels, which confirms validity of lesson planning kill observation card.

2. Reliability coefficient between first and second application of lesson planning kill observation card for pilot sample

Table (5)

Significance of differences between the first and second implementations of the observation card of the Lesson planning skill for the pilot sample

\begin{tabular}{|c|c|c|c|c|c|c|c|c|c|}
\hline \multirow{2}{*}{ Statistics } & \multirow{2}{*}{$\begin{array}{c}\text { Measurement } \\
\text { unit }\end{array}$} & \multicolumn{2}{|c|}{$\mathbf{1}^{\text {st }}$ application } & \multicolumn{2}{|c|}{$2^{\text {nd }}$ application } & \multicolumn{2}{|c|}{$\begin{array}{c}\text { Difference } \\
\text { between means }\end{array}$} & \multirow{2}{*}{$\begin{array}{c}(\mathbf{T}) \\
\text { value }\end{array}$} & \multirow{2}{*}{$\begin{array}{c}(\mathbf{R}) \\
\text { Value } \\
\text { (reliability) }\end{array}$} \\
\hline & & Mean & $\begin{array}{l}\text { Standard } \\
\text { deviation }\end{array}$ & Mean & $\begin{array}{l}\text { Standard } \\
\text { deviation }\end{array}$ & Mean & $\begin{array}{l}\text { Standard } \\
\text { deviation }\end{array}$ & & \\
\hline
\end{tabular}




\begin{tabular}{l|l|l|l|l|l|l|l|l|l}
\hline \hline Lesson planning skill & Marks & 41.70 & 4.02 & 42.26 & 3.53 & -0.57 & 2.21 & 1.22 & $0.836^{*}$ \\
\hline \hline
\end{tabular}

* Significant at 0.05 level $(\mathrm{T}$ critical $=2.07)$

* Significant at 0.05 level $(\mathrm{R}$ critical $=0.404)$

Table (5) results reveal that difference between the two implementations was not significant where the calculated $\mathrm{T}(1.22)$ is less than $(\mathrm{T})$ critical at (0.05) level, reliability coefficient was $(0.836)$ a value which is greater than $(\mathrm{R})$ critical at $(0.05)$ level, which confirms that observation card phrases are reliable and gives the same results if re-applied on same sample and in the same conditions.

\section{Objectivity of lesson planning kill observation card}

Table (6)

Differences between first and second judges to find the objectivity of the observation card of the Lesson planning skill

\begin{tabular}{|c|c|c|c|c|c|c|c|}
\hline \multirow{2}{*}{ variables Statistics } & \multirow{2}{*}{$\begin{array}{c}\text { Measurement } \\
\text { unit }\end{array}$} & \multicolumn{2}{|c|}{$\begin{array}{l}1^{\text {st }} \text { judge } \\
(n=24)\end{array}$} & \multicolumn{2}{|c|}{$\begin{array}{c}2^{\text {nd }} \text { judge } \\
(n=24)\end{array}$} & \multirow{2}{*}{$\begin{array}{c}\text { Difference } \\
\text { between } \\
\text { means }\end{array}$} & \multirow{2}{*}{$\begin{array}{l}(\mathbf{T}) \\
\text { value }\end{array}$} \\
\hline & & Mean & $\begin{array}{l}\text { Standard } \\
\text { deviation }\end{array}$ & Mean & $\begin{array}{l}\text { Standard } \\
\text { deviation }\end{array}$ & & \\
\hline $\begin{array}{c}\text { Lesson planning } \\
\text { skill }\end{array}$ & "marks & 1.63 & 0.50 & $\overline{1.71}$ & 0.46 & $\begin{array}{c}0.08 \\
\end{array}$ & 0.602 \\
\hline
\end{tabular}

* Significant at 0.05 level ( $\mathrm{T}$ critical $=2.01)$

Table (6) results revealed that the difference between the two judges was not statistically significant where $t$ calculated value $(0.602)$ is lower than $\mathrm{T}$ critical at 0.05 , the matter which confirms that judges' marks are very close and high objectivity. Hence the observation card of the Lesson planning skill is valid, reliable and objective and could be applied.

\section{B- Designing Attitudes Scale was as the following steps:}

1. Determining attitudes scale 2. Identifying scale aspects and phrases 3-Developing and wording scale phrases 4. Developing appropriate scale' instructions 5. Determining the test's time 6- scale scientific standards 7 - scale in its final form.

- Validity and reliability of attitudes scale:

2- Validity: researchers have used:

- Internal consistency coefficient. (appendix 9)

- Comparison between highest and lowest quartiles for lesson planning kill observation card as illustrated by the following table:

Table (7)

Comparison between highest and lowest quartiles for attitudes scale

\begin{tabular}{|c|c|c|c|c|c|c|c|c|}
\hline \multirow{2}{*}{ variables } & \multirow{2}{*}{$\begin{array}{c}\text { Measurement } \\
\text { unit }\end{array}$} & \multicolumn{2}{|c|}{$\begin{array}{c}\text { Highest quartile } \\
(\mathrm{n}=8)\end{array}$} & \multicolumn{2}{|c|}{$\begin{array}{c}\text { Lowest quartile } \\
(\mathrm{n}=8)\end{array}$} & \multirow{2}{*}{$\begin{array}{c}\text { Difference } \\
\text { between means }\end{array}$} & \multirow{2}{*}{$\begin{array}{l}(\mathrm{T}) \\
\text { value }\end{array}$} & \multirow{2}{*}{$\begin{array}{c}\text { Validity } \\
\text { coefficient }\end{array}$} \\
\hline & & Mean & $\begin{array}{l}\text { Standard } \\
\text { deviation }\end{array}$ & Mean & $\begin{array}{l}\text { Standard } \\
\text { deviation }\end{array}$ & & & \\
\hline Attitudes scale & Marks & 82.76 & 4.23 & 59.5 & 10.92 & 23.25 & $5.62 *$ & 82.23 \\
\hline
\end{tabular}

* Significant at 0.05 level $(\mathrm{T}$ critical $=2.14)$

Table (7) results reveal a presence of statistically significant differences between highest and lowest quartiles as $\mathrm{T}$ calculated value (5.62) is greater than the $\mathrm{T}$. critical value at 0.05 levels, which confirms validity of attitudes scale.

2. Reliability coefficient between first and second implementations of attitudes scale for the pilot's sample.

Table (8)

Significance of differences first and second implementations of attitudes scale for the pilot's sample 
$(\mathrm{n}=14)$

\begin{tabular}{|c|c|c|c|c|c|c|c|c|c|}
\hline \multirow{2}{*}{ variables } & \multirow{2}{*}{$\begin{array}{l}\text { Measurement } \\
\text { unit }\end{array}$} & \multicolumn{2}{|c|}{$1^{\text {st }}$ application } & \multicolumn{2}{|c|}{$2^{\text {nd }}$ application } & \multicolumn{2}{|c|}{$\begin{array}{c}\text { Difference } \\
\text { between means }\end{array}$} & \multirow{2}{*}{$\begin{array}{l}(\mathrm{T}) \\
\text { value }\end{array}$} & \multirow{2}{*}{$\begin{array}{c}(\mathbf{R}) \\
\text { Value } \\
\text { (reliability) }\end{array}$} \\
\hline & & Me & $\begin{array}{l}\text { Standard } \\
\text { deviation }\end{array}$ & Mean & $\begin{array}{l}\text { Standard } \\
\text { deviation } \\
\end{array}$ & Mean & $\begin{array}{l}\text { Standard } \\
\text { deviation }\end{array}$ & & \\
\hline "attitudes scale & Marks & 71.07 & 11.08 & 71.07 & 11.08 & 0.00 & 0.00 & 0.00 & 1.00 \\
\hline
\end{tabular}

* Significant at 0.05 level ( $\mathrm{T}$ critical $=2.16)$

* Significant at 0.05 level $(\mathrm{R}$ critical $=0.532)$

Table (8) results reveal that difference between the two implementations was not significant as $(\mathrm{t})$ calculated $(0.00)$ is less than $(\mathrm{T})$ critical at $(0.05)$ level, reliability coefficient was (1.00) a value which is greater than (R) critical at (0.05) level, which confirms that attitudes scale phrases are reliable and gives the same results if re-applied on same sample and in the same conditions

\section{C- Designing theoretical lectures based on Six Thinking Hats strategy:}

- Steps of Lectures Design and Preparation:

Researcher reviewed some scientific studies such as Alaweidy (2011), Fahd Al Shaya, and Al-Oqil (2009), as well as academic literature and references such as Al-Gyoshi (2001) for these scientific steps. Edward de Bono has developed teaching method and designing steps using Six Thinking Hats as the following: (1- Setting goals for proposed theory lectures 2- Identifying of procedural objectives of sessions or lectures 3-Selecting of lectures content from syllabus description 4- Identifying proposed application methods and styles 5. Identifying educational activities and teaching aids to be used in lectures 6 . Determining evaluation methods in lectures 7- Presenting proposed lectures to arbitrators 8- Determining time period for the implementation of theoretical lectures).

- Expert's validity of theoretical lectures design based on Six Thinking Hats strategy (appendix 10).

VI- Statistical processes:

The researchers used the appropriate statistical processes to research nature using statistical packages (SPSS), including:

(Mean - standard deviation - frequencies, percentages - paired $(\mathrm{T})$ value- relative importance correlation coefficient - internal consistency coefficient - Cronbach alpha coefficient - skewness coefficient).

VII- Results and discussion:-

1. Results and discussion of the effect of the experimental absolute variable for lesson planning skills for both groups:

Table (9)

Significance of differences between post measurements means of experimental and control groups in lesson planning skill after experiment implementation

\begin{tabular}{|c|c|c|c|c|c|c|c|c|}
\hline Statistics & \multirow{2}{*}{$\begin{array}{c}\text { Measurement } \\
\text { unit }\end{array}$} & \multicolumn{2}{|c|}{$\begin{array}{c}\text { experimental } \\
\text { group } \\
(\mathbf{n}=\mathbf{3 5}) \\
\end{array}$} & \multicolumn{2}{|c|}{$\begin{array}{l}\text { control group } \\
\quad(\mathbf{n}=\mathbf{3 5})\end{array}$} & \multirow{2}{*}{$\begin{array}{c}\text { Difference } \\
\text { Between } \\
\text { means }\end{array}$} & \multirow{2}{*}{$\begin{array}{c}(\mathrm{T}) \\
\text { value }\end{array}$} & \multirow{2}{*}{$\begin{array}{l}\text { Difference } \\
\text { percentage }\end{array}$} \\
\hline vari & & Mean & $\begin{array}{l}\text { Standard } \\
\text { deviation }\end{array}$ & Mean & $\begin{array}{l}\text { Standard } \\
\text { deviation }\end{array}$ & & & \\
\hline $\begin{array}{l}\text { Lesson planning } \\
\text { skill }\end{array}$ & "marks & "61.94 & 7.98 & 33.97 & 5.15 & 27.97 & "17.41* & 82.34 \\
\hline
\end{tabular}

* Significant at 0.05 level $(\mathrm{T}$ critical $=2.00)$ 


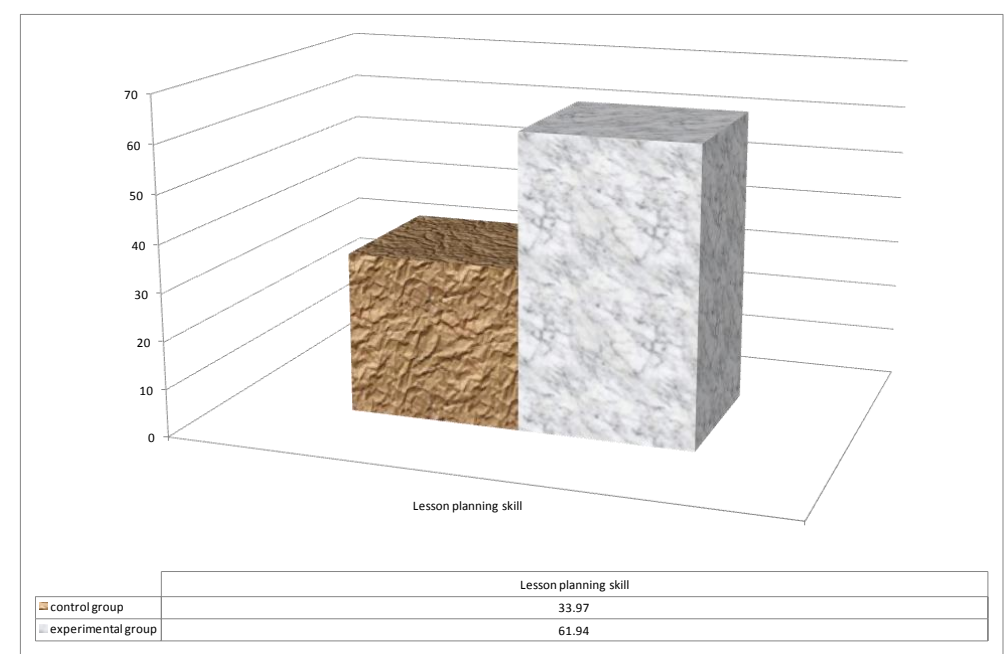

Figure (1)

Means of experimental and control groups in lesson planning skill after experiment implementation

Table (9) results and figure (1) reveal presence of significant differences between experimental and control groups in the observation card of lesson planning skill after experiment implementation in favor of experimental group where $\mathrm{T}$ calculated value (17.4) is greater than $\mathrm{T}$ critical at 0.05 level, and the difference percentage was $(82.34 \%)$ in favor of the experimental group. Researchers attribute presence of statistically significance difference in all sentences of the observation card of lesson planning skill in good planning and preparation in favor to the experimental group. Researchers believe that planning process depends on knowledge of good planning rules and components; which lead to constant communication in addition to that Six Thinking Hats give students the opportunity for increase knowledge and information related to teaching skills (lesson planning skill) under study from behavioral objectives. Also it allows availability of various sources of information, dealing with what six thinking hats contain from learning methods and means, and students engagement in teaching process giving the students the opportunity to increase knowledge and continuous learning. This is in line with recent trends in educational process which are based on learning that take individual differences into account, These findings are consistent with the results of Alaweidy's (2011) study which indicated that using six thinking hats strategy with the experimental group was of the most important methods and ways of developing creativity in thinking and giving the thinking process the required time and effort. Creative process is based on a very important matter namely; organized thinking style and mental and intellectual dealing with good planning. These results are also consistent with Cotton (1997) who asks a faculty staff member to play a role as a creative lecturer and researcher, educator, guider, leader and creators discoverer and trainer during under and post graduate university studies, She/he should know that thinking could be taught and developed, through six hats strategies, particularly in the area of teaching and learning, including Physical Education. Six hats strategy dramatically contributed in experimental group improvement in lesson planning skill.

2. Results and discussion of experimental group results of lesson planning skills:

Table (10) significance of differences between experimental group's pre and post measurements in lesson planning skill

\begin{tabular}{|c|c|c|c|c|c|c|c|c|c|}
\hline & & & & & & & & & $\mathbf{n}=?$ \\
\hline \multirow{2}{*}{ variables } & \multirow{2}{*}{$\begin{array}{c}\text { Measurement } \\
\text { unit }\end{array}$} & \multicolumn{2}{|c|}{ Pre measurement } & \multicolumn{2}{|c|}{$\begin{array}{c}\text { Post } \\
\text { measurement }\end{array}$} & \multicolumn{2}{|c|}{$\begin{array}{c}\text { Difference } \\
\text { between means }\end{array}$} & \multirow{2}{*}{$\begin{array}{c}(\mathbf{T}) \\
\text { value }\end{array}$} & \multirow{2}{*}{$\begin{array}{c}\text { Improvement } \\
\text { percentage }\end{array}$} \\
\hline & & Mean & $\begin{array}{l}\text { Standard } \\
\text { deviation }\end{array}$ & Mean & $\begin{array}{l}\text { Standard } \\
\text { deviation }\end{array}$ & Mean & $\begin{array}{l}\text { Standard } \\
\text { deviation }\end{array}$ & & \\
\hline $\begin{array}{c}\text { Lesson } \\
\text { planning skill } \\
\end{array}$ & Marks & 33.23 & 3.94 & 61.94 & 7.99 & 28.71 & 10.07 & $16.87 *$ & $86.41 \%$ \\
\hline
\end{tabular}

* Significant at 0.05 level $(\mathrm{T}$ critical $=2.03)$ 


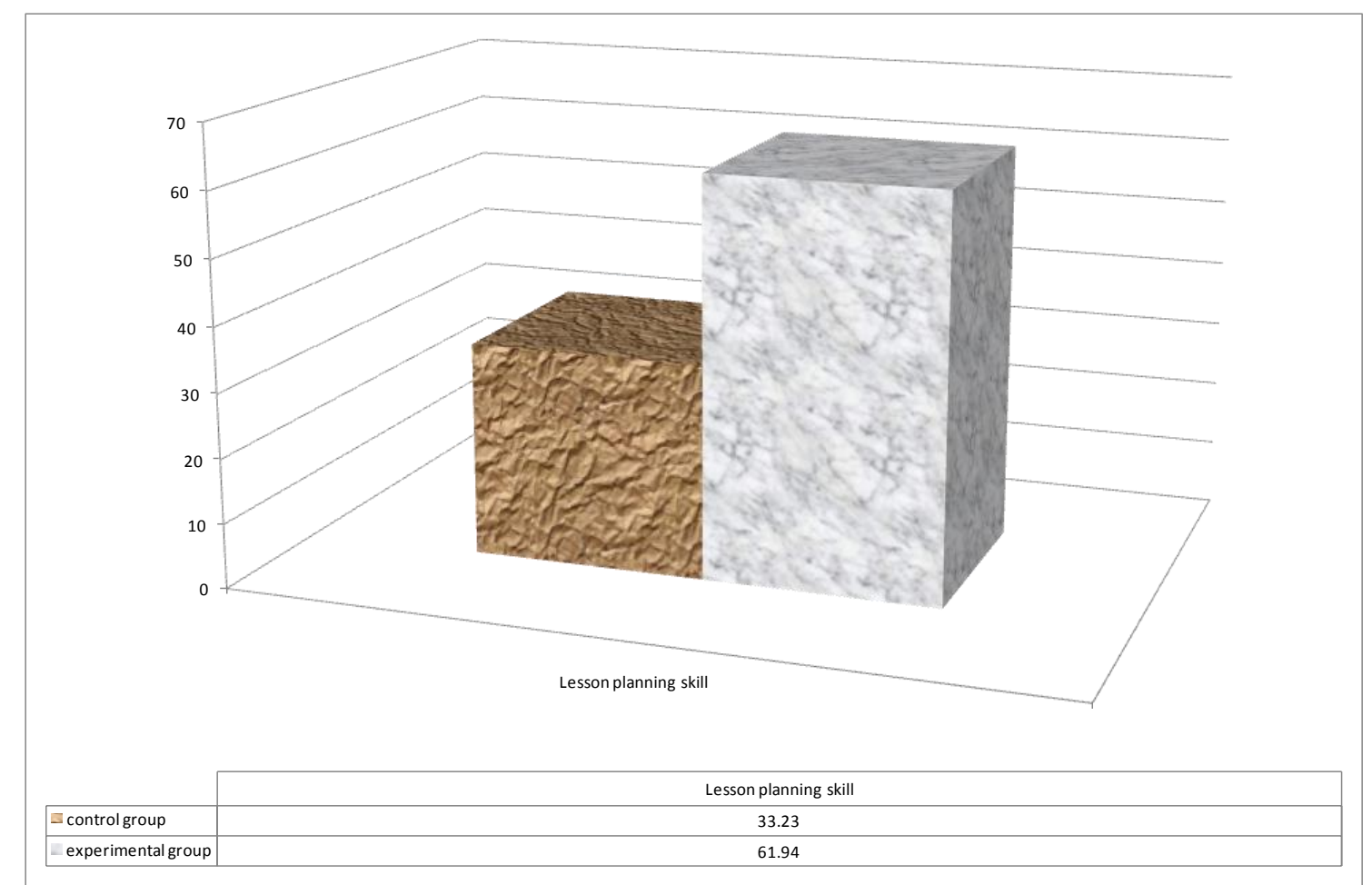

Figure (2)

Means of experimental groups pre and post measurements in lesson planning skill

Table (10) results and figure (2) reveal presence of significant differences between pre and post measurements of experimental groups in the observation card of lesson planning skill in favor of post measurement where $\mathrm{T}$ calculated value (16.87) is greater than $\mathrm{T}$ critical at 0.05 levels, and the improvement percentage was $(86.41 \%)$. Researchers attribute this to lessons preparation on a regular basis, also maintaining a range lesson planning models to discuss these models with students which helped in developing their lesson planning skill, in addition to lessons prepared by the researcher, viewing and analyze all information and elements lead to good lessons planning, all these points helped students to develop their lesson planning skills. These results are in line with what referred by Abdul-Aziz $(2001,57)$ that teaching planning skills for student teacher achieved highest level of other skills in interest in preparation, neatness, determine class objectives, commitment to preparation from physical education syllabus units, and presenting lesson in terms of graphics and appropriate formations (2:57). This result also agrees with Pal $(2004,19)$ study, which emphasizes that who wear the yellow hat would be optimistic and positive, focus on success possibilities more than failure ones. This helped experimental group students in good lessons planning

\section{Results and discussion of experimental group results of lesson planning skills:}

Table (11) significance of differences between control group's pre and post measurements in lesson planning skill

$\mathbf{n}=\mathbf{3 5}$

\begin{tabular}{|c|c|c|c|c|c|c|c|c|c|}
\hline \multirow{2}{*}{ variables } & \multirow{2}{*}{$\begin{array}{c}\text { Measurement } \\
\text { unit }\end{array}$} & \multicolumn{2}{|c|}{ Pre measurement } & \multicolumn{2}{|c|}{$\begin{array}{c}\text { Post } \\
\text { measurement }\end{array}$} & \multicolumn{2}{|c|}{$\begin{array}{c}\text { Difference } \\
\text { between means }\end{array}$} & \multirow{2}{*}{$\begin{array}{c}(\mathrm{T}) \\
\text { value }\end{array}$} & \multirow{2}{*}{$\begin{array}{c}\text { Improvement } \\
\text { percentage }\end{array}$} \\
\hline & & Mean & $\begin{array}{l}\text { Standard } \\
\text { deviation }\end{array}$ & Mean & $\begin{array}{l}\text { Standard } \\
\text { deviation }\end{array}$ & Mean & $\begin{array}{l}\text { Standard } \\
\text { deviation }\end{array}$ & & \\
\hline $\begin{array}{c}\text { Lesson } \\
\text { planning skill }\end{array}$ & Marks & 29.83 & 3.91 & 33.97 & 5.15 & 4.14 & 7.19 & $3.41 *$ & 13.89 \\
\hline
\end{tabular}

* Significant at 0.05 level $(\mathrm{T}$ critical $=2.03$ ) 


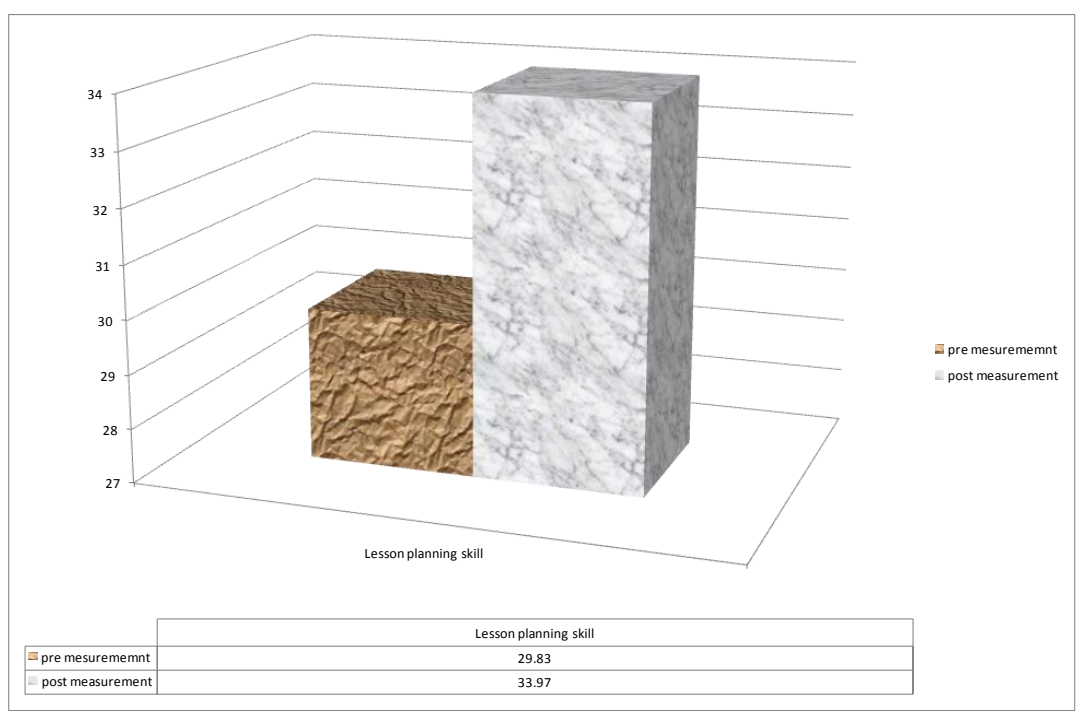

Figure (3)

Means of experimental groups pre and post measurements in lesson planning skill

Table (11) results and figure (2) reveal presence of significant differences between pre and post measurements of control groups in the observation card of lesson planning skill in favor of post measurement where $\mathrm{T}$ calculated value (3.41) is greater than $\mathrm{T}$ critical at 0.05 level, and the improvement percentage was $(13.89 \%)$.Researcher attribute this improvement to that students have acquired some extra information and knowledge about lesson planning skill, as well as this sample have used student teacher's guide where there is range of knowledge and information about lesson planning, the guide also contains range of physical education sample lessons, which can be used by the student, and through it he can plan similar models, This is agreed with Bailey $(2003,23)$, argument that teaching may involve set of challenges, and effective planning is among the best tools that teacher may use in facing these challenges. planning process take some time, but it is usually beneficial, moreover, planning is one of teacher work aspects which remain under their direct control. These is also in line with Said (2009, 97) study results which revealed indoctrination (explanation and model performance) positively contributed in improving teaching skills performance level as well as improving knowledge achievement of control group members.

3. Results and discussion of students' attitudes towards teaching using six thinking hats strategy after experiment:

Table (12)

Frequency, percentage and statistics significance of responses to attitudes scale (1- trends)

$$
\mathrm{n}=35
$$

\begin{tabular}{|c|c|c|c|c|c|c|c|c|c|c|}
\hline \multirow{2}{*}{ Phrase } & \multirow{2}{*}{ Aspect } & \multicolumn{2}{|c|}{ Yes } & \multicolumn{2}{|c|}{ To some extent } & \multicolumn{2}{|c|}{ No } & \multirow{2}{*}{$\begin{array}{c}\text { Chi } \\
\text { square }\end{array}$} & \multirow{2}{*}{ Significance } & \multirow{2}{*}{$\begin{array}{r}\text { Approval } \\
\text { Percentage }\end{array}$} \\
\hline & & Freq. & $\%$ & Freq. & $\%$ & Freq. & $\%$ & & & \\
\hline 1 & \multirow{17}{*}{$\underset{\sim}{\stackrel{0}{0}}$} & 29 & $82.86 \%$ & 5 & $14.29 \%$ & 1 & $2.86 \%$ & 39.314 & 0.000 & $90.00 \%$ \\
\hline 2 & & 27 & $77.14 \%$ & 7 & $20.00 \%$ & 1 & $2.86 \%$ & 31.771 & 0.000 & $87.14 \%$ \\
\hline 3 & & 27 & $77.14 \%$ & 7 & $20.00 \%$ & 1 & $2.86 \%$ & 31.771 & 0.000 & $87.14 \%$ \\
\hline 4 & & 27 & $77.14 \%$ & 8 & $22.86 \%$ & 0 & $0.00 \%$ & 10.314 & 0.001 & $88.57 \%$ \\
\hline 5 & & 0 & $0.00 \%$ & 7 & $20.00 \%$ & 28 & $80.00 \%$ & 12.6 & 0.000 & $10.00 \%$ \\
\hline 6 & & 28 & $80.00 \%$ & 7 & $20.00 \%$ & 0 & $0.00 \%$ & 12.6 & 0.000 & $90.00 \%$ \\
\hline 7 & & 27 & $77.14 \%$ & 8 & $22.86 \%$ & 0 & $0.00 \%$ & 10.314 & 0.001 & $88.57 \%$ \\
\hline 8 & & 15 & $42.86 \%$ & 18 & $51.43 \%$ & 2 & $5.71 \%$ & 12.4 & 0.002 & $68.57 \%$ \\
\hline 9 & & 0 & $0.00 \%$ & 0 & $0.00 \%$ & 35 & $100.00 \%$ & 0 & 0 & $0.00 \%$ \\
\hline 10 & & 0 & $0.00 \%$ & 0 & $0.00 \%$ & 35 & $100.00 \%$ & 0 & 0 & $0.00 \%$ \\
\hline 11 & & 20 & $57.14 \%$ & 15 & $42.86 \%$ & 0 & $0.00 \%$ & 0.714 & 0.398 & $78.57 \%$ \\
\hline 12 & & 27 & $77.14 \%$ & 8 & $22.86 \%$ & 0 & $0.00 \%$ & 10.314 & 0.001 & $88.57 \%$ \\
\hline 13 & & 27 & $77.14 \%$ & 7 & $20.00 \%$ & 1 & $2.86 \%$ & 31.771 & 0.000 & $87.14 \%$ \\
\hline 14 & & 29 & $82.86 \%$ & 6 & $17.14 \%$ & 0 & $0.00 \%$ & 15.114 & 0.000 & $91.43 \%$ \\
\hline 15 & & 25 & $71.43 \%$ & 8 & $22.86 \%$ & 2 & $5.71 \%$ & 24.4 & 0.000 & $82.86 \%$ \\
\hline 16 & & 0 & $0.00 \%$ & 0 & $0.00 \%$ & 35 & $100.00 \%$ & 0 & 0 & $0.00 \%$ \\
\hline 17 & & 30 & $85.71 \%$ & 5 & $14.29 \%$ & 0 & $0.00 \%$ & 17.857 & 0.000 & $92.86 \%$ \\
\hline
\end{tabular}


Table (12) results revealed that experimental group responses for attitudes scale (1trends) phrases was with approval percentage ranged between $(10.00 \%$ and $92.86 \%$ ), with highest approval for statement no 17 (wish to present some educational videos using six thinking hats about physical education lesson planning), and the lowest approval was for statement no 5 (feels that learning lesson planning skill using six thinking hats is waste of time and effort). Chisquare ranged between (10.314 and 39.314\%), and achieved significant differences in most of phrases at 0.05 level.

Table (13)

Frequency, percentage and statistics significance of responses to attitudes scale (2tendencies)

\begin{tabular}{|c|c|c|c|c|c|c|c|c|c|c|}
\hline & & & & & & & & & & $\mathbf{n}=35$ \\
\hline \multirow{2}{*}{ Phrase } & \multirow{2}{*}{ Aspect } & \multicolumn{2}{|c|}{ Yes } & \multicolumn{2}{|c|}{ To some extent } & \multicolumn{2}{|c|}{ No } & \multirow{2}{*}{$\begin{array}{c}\text { Chi } \\
\text { square }\end{array}$} & \multirow{2}{*}{ Significance } & \multirow{2}{*}{\begin{tabular}{|c|} 
Approval \\
Percentage
\end{tabular}} \\
\hline & & Freq. & $\%$ & Freq. & $\%$ & Freq. & $\%$ & & & \\
\hline 18 & \multirow{6}{*}{ 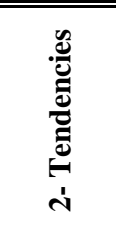 } & 31 & $88.57 \%$ & 4 & $11.43 \%$ & 0 & $0.00 \%$ & 20.829 & 0.000 & $94.29 \%$ \\
\hline 19 & & 25 & $71.43 \%$ & 10 & $28.57 \%$ & 0 & $0.00 \%$ & 6.429 & 0.011 & $85.71 \%$ \\
\hline 20 & & 30 & $85.71 \%$ & 4 & $11.43 \%$ & 1 & $2.86 \%$ & 43.6 & 0.000 & $91.43 \%$ \\
\hline 21 & & 25 & $71.43 \%$ & 8 & $22.86 \%$ & 2 & $5.71 \%$ & 24.4 & 0.000 & $82.86 \%$ \\
\hline 22 & & 0 & $0.00 \%$ & 8 & $22.86 \%$ & 27 & $77.14 \%$ & 10.314 & 0.001 & $11.43 \%$ \\
\hline 23 & & 30 & $85.71 \%$ & 4 & $11.43 \%$ & 1 & $2.86 \%$ & 43.6 & 0.000 & $91.43 \%$ \\
\hline
\end{tabular}

Table (13) results revealed that experimental group responses for attitudes scale (2tendencies) phrases was with approval percentage ranged between (11.43\% and $94.29 \%)$, with highest approval for statement no 18 ( always acquaintance with the new about lesson planning models), and the lowest approval was for statement no 22 (feels non concentration or interest when learn lesson planning using six thinking hats). Chi-square ranged between (10.314 and 43.6\%), and achieved significant differences in most of phrases at 0.05 level.

\section{Table (14)}

Frequency, percentage and statistics significance of responses to attitudes scale (3commitment to professional ethics in word and deed) $n=35$

\begin{tabular}{|c|c|c|c|c|c|c|c|c|c|c|}
\hline \multirow{2}{*}{ Phrase } & \multirow{2}{*}{ Aspect } & \multicolumn{2}{|c|}{ Yes } & \multicolumn{2}{|c|}{ To some extent } & \multicolumn{2}{|c|}{ No } & \multirow{2}{*}{$\begin{array}{c}\text { Chi } \\
\text { square }\end{array}$} & \multirow{2}{*}{ Significance } & \multirow{2}{*}{$\begin{array}{r}\text { Approval } \\
\text { Percentage }\end{array}$} \\
\hline & & Freq. & $\%$ & Freq. & $\%$ & Freq. & $\%$ & & & \\
\hline 24 & \multirow{7}{*}{ 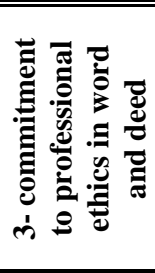 } & 30 & $85.71 \%$ & 5 & $14.29 \%$ & $\mathbf{0}$ & $0.00 \%$ & $\mathbf{1 7 . 8 5 7}$ & 0.000 & $92.86 \%$ \\
\hline 25 & & 26 & $74.29 \%$ & 9 & $25.71 \%$ & $\mathbf{0}$ & $\mathbf{0 . 0 0 \%}$ & 8.257 & 0.004 & $87.14 \%$ \\
\hline 26 & & 30 & $85.71 \%$ & 5 & $14.29 \%$ & $\mathbf{0}$ & $0.00 \%$ & 17.857 & 0.000 & $92.86 \%$ \\
\hline 27 & & 27 & $77.14 \%$ & 7 & $20.00 \%$ & 1 & $2.86 \%$ & 31.771 & 0.000 & $87.14 \%$ \\
\hline 28 & & 32 & $91.43 \%$ & 3 & $8.57 \%$ & $\mathbf{0}$ & $0.00 \%$ & 24.029 & 0.000 & $95.71 \%$ \\
\hline 29 & & 30 & $85.71 \%$ & 4 & $11.43 \%$ & 1 & $2.86 \%$ & 43.6 & 0.000 & $91.43 \%$ \\
\hline 30 & & 31 & $88.57 \%$ & 4 & $11.43 \%$ & $\mathbf{0}$ & $0.00 \%$ & 20.829 & 0.000 & $94.29 \%$ \\
\hline
\end{tabular}

Table (14) results revealed that experimental group responses for attitudes scale (3commitment to professional ethics in word and deed) phrases was with approval percentage ranged between (87.14\% and 95.71\%), with highest approval for statement no 28 (Consider honest in acquiring knowledge and information while planning physical education lessons for learners in internal field training), and the lowest approval was for statement no 25 and 27 (learning lesson planning by using six thinking hats developed my leadership skill in theoretical and practical teaching situations and Organized teaching situation in planning to achieve the desired objective in internal field training). Chi-square ranged between (8.257 and 31.771\%), and achieved significant differences in most of phrases at 0.05 level.

Table $(12,13$ and 14) results indicate that there are significant differences in response level in direction of approval to use six thinking hats. Researches return this improvement to that students have acquired some additional information and knowledge about lesson planning skill, and proper use of media such as pictures and graphics, sound effects. Internet and some Lessons planning were behind the developing the positive attitude towards use of Six Thinking Hats. This result is consistent with Alaweidy (2011) study results.

The researchers explain this result by the following: 
1- Using six thinking hats methods, techniques and steps and what gets from ease of accessing to information as opposed to traditional strategies and methods.

2- Direct viewing of different teaching methods (lecture, question and answer, discussion, survey, brainstorming .....) which presented by the researcher inside the lecture, explaining how to teach lectures and contents with different methods and styles, and viewing and lessons planning facilitate teaching process and give appropriate Visualization, which had a great effect on developing positive attitude towards Six Thinking Hats.

3- Getting benefit from six thinking hats advantages in developing and improving the attitude towards it.

\section{VIII- conclusions:}

1- There is an improvement between the pre and post measurements of the control group in lesson planning skill in favor of the post measurement.

2- There are statistically significant differences between the pre and post measurements of the experimental group (six thinking hats) in lesson planning skill in favor of the post measurement.

3- There are statistically significant differences between the post measurements of the control and experimental groups in lesson planning skill in favor of the experimental group.

4- There is a clear superiority of experimental group (Six Thinking Hats) over the control group (traditional method) in lesson planning skill.

5- There are statistically significant differences in the experimental group's responses according to the Attitudes Scale towards six thinking hats in direction of approval..

\section{IX- Recommendations:}

1. Amending faculty's bylaw by increasing the hours allocated to Internal Field Practicum to include (theoretical and practical) hours instead of (theoretical) hours only.

2. Using the Proposed program's contents in teaching the students who study Internal Field Practicum course to improve the skill of lesson planning.

3. It's important to use the Six Thinking Hats strategy in teaching theoretical aspects of academic syllabuses.

4. Using the evaluation form used in the current research in evaluating students who study the Internal Field Practicum course.

5. Conducting further studies to identify six thinking hats' effectiveness on other teaching skills within the Internal Field Practicum syllabus.

6. Conducting further studies to identify six thinking hats' effectiveness on theoretical subjects in Physical Education.

7. Conducting further studies to identify six thinking hats effectiveness on developing the skills of Physical Education teachers and guiders.

8. Preparing Seminars and courses for teaching staff members about using six thinking hats strategy because of its significant role in delivering information, knowledge and development of creative thinking.

9. Conducting more studies to identify the most appropriate teaching methods that can be used with Six Thinking Hats in Physical Education. 


\section{References}

Abdul-Aziz, Tahany (2001).Teaching skills and their relationship with commitment and excellence in field training for student teacher in physical education. Assiut Journal of Physical Education Science and Arts. issue 13, Part 1.

Abdullah, Essam El-Din Metwally and Badawi, Badawi Abdel-AAl(2006).Teaching physical education methods between theory and application, Alexandria: :Knowledge House. (in Arabic Language)

Al Shaya, Fahad, and Al-Oqil, Mohammed bin Abdulaziz (2009). The effect of using the Six Thinking Hats in teaching science on development of creative thinking and verbal classroom interaction for sixth grade students in Riyadh. Excellence Center for Research in developing science and math education. King Saud University. (in Arabic Language)

Al-Aweida, Wafaa Hafez (2011). Effectiveness of an educational unit based on Six Thinking Hats program on development of creative teaching skills for Arabic language student teachers in middle school and their attitudes towards it, Theories and applications in curricula and Arabic language teaching methods. Faculty of Education at King Abdul Aziz University in Jeddah. (in Arabic Language)

Al-Diwan, Lamias(2009). Teaching skills. Available at http://forum.iraqacad.org/viewtopic.php? $\mathrm{F}=44 \& \mathrm{t}=1182$. (in Arabic language)

Al-Gyoshi Khalil (2001). Six Thinking Hats. Abu Dhabi: Cultural Foundation. (in Arabic Language)

Bailey, Richard (2003). Guide if teaching physical education in schools. Education development series. Translated by Tip Top Arabization and translation. Cairo: Al-Farouk for publication and distribution. (in Arabic Language)

Brown, George (2005).Mini teaching and Filed Education training. Translated by Mohammad Reza Al-Baghdadi and Hayam Mohammed Al-Baghdadi. $2^{\text {nd }}$ ed. Cairo: Arab Thought House. (in Arabic Language)

Cotton, (1997). Teaching Thinking Skill School Improvement Research Serious. USA: SIRS,

Elfar, Ibrahim Abdalwakel (2002). Leading researches in computer educational, using computer and information technology in teaching and learning processes. Faculty of Education-Tanta University. (in Arabic Language)

Gaber, Gaber Abdel-Hamid (1998). Teaching and learning: theoretical foundations - strategies and effectiveness. Cairo : Arab Thought House, (in Arabic Language)

Hecerian, B.S.(2004).The effects of six thinking method on effective learning in biology. The fifth international conference on creative thinking. University of Malta.

Mahmoud, Salah al-Din Arafa (2005). Education skills teaching individualization between theory and application. Cairo. (in Arabic language)

Omar, Zainab Ali and Abdel-Karim, Ghada Galal(2007). Physical education teaching methods: theoretical foundations and practical applications. Cairo: Arab Thought House. (in Arabic Language)

Pal, p. six thinking hats, retieved,oct3 (2004),,from/ www.geocities.co.

Said, Heba Abdel Moneim (2009). Building an educational site and its effect on acquisition of some teaching skills for field training students in teaching section, Faculty of Physical Education in Tanta. Master Thesis. Faculty of Physical Education in Tanta. Tanta University. (in Arabic Language) 
Salem, Wafika Mustafa (1998) Water sports: methods of teaching, training foundations, evaluation methods. Alexandria University: University books publishing organization. (in Arabic language).

Shehata, Hassan(1998). School curricula between theory and application, Cairo: Arab Book House. (in Arabic Language)

Teaima, Ahmed Rushdie(1999). Teacher: competencies, preparation, training, Cairo: Arab Thought House.. (in Arabic Language)

Zeiton, Kamal Abdul Hamid (1997). Teaching: models and skills. Alexandria: Scientific Office for computer, publishing and distribution. (in Arabic Language)

http://www.sandroses.com/abbs/t142411

http://www.sarkosa.com/vb/t46094 10/04 / 2009

http://www.illumine.co.uk/innovate/debono-six-thinking-hats.htm $22 \backslash 06 \backslash 2009$

http://www.hiyat.net/vb/showthread.php?t=14124 $19 \backslash 05 \backslash 2009$

http://www.ksa-teachers.com/forums/f28/t-5510.html 13 \07\2009 


\section{Appendix (1)}

\section{Observation Form of Internal Field Practicum Course}

\begin{tabular}{|c|c|c|c|}
\hline Aspect & Phrase & Yes & No \\
\hline $\mathbf{I}$ & Teaching Methods & & \\
\hline 1. & Lecturer's ability to raise students' interest about lecture topic. & & \\
\hline 2 & He uses s clear, simple and interesting style during explanation. & & \\
\hline 3 & He asks questions to students and listens to their answers with attention. & & \\
\hline 4. & He uses both whole and part methods in teaching skills. & & \\
\hline 5. & He gives the opportunity to learners to invent new methods. & & \\
\hline II & Educational Aids and Modern Techniques & & \\
\hline 1. & He uses modern means and techniques inside lecture room. & & \\
\hline 2. & He uses alternative tools in teaching and learning teaching skills. & & \\
\hline 3 & He finds modern tools to overcome students' congestion. & & \\
\hline III & Students Behavior & & \\
\hline 1. & Students participate during lectures with discussion or inquiry. & & \\
\hline 2. & $\begin{array}{l}\text { Students personally get benefit from this syllabus in terms of understanding } \\
\text { acquisition of teaching skills. }\end{array}$ & & \\
\hline 3. & $\begin{array}{l}\text { Pre- readiness of students to read and train on the syllabus (theoretical and } \\
\text { practical) }\end{array}$ & & \\
\hline IV & Lesson Planning & & \\
\hline 1 & Identifying and wording teaching objectives correctly. & & \\
\hline 2 & Determining the time periods for each lesson part. & & \\
\hline 3 & Identifying teaching methods and styles used in the lesson & & \\
\hline 4. & Identifying and select proper teaching tools and aids. & & \\
\hline 5. & Identifying evaluation methods inside lessons. & & \\
\hline 6. & $\begin{array}{l}\text { Writing and drafting physical exercise, according to the terms of writing } \\
\text { and calling. }\end{array}$ & & \\
\hline 7. & Selecting sports skills and activities, according to the age stages . & & \\
\hline 8. & $\begin{array}{l}\text { Determining the lessons nature in accordance with weather and } \\
\text { environment conditions. }\end{array}$ & & \\
\hline
\end{tabular}


Appendix (2)

Statement of Students' Success Rate in Internal Field Practicum Course in 2013/2014 academic year, Faculty of Physical Education for Men, Alexandria University

\begin{tabular}{|l|l|l|}
\hline Merit & students number & Percentage \\
\hline Excellent & 29 & $8.8 \%$ \\
\hline Very good & 55 & $16.7 \%$ \\
\hline Good & 99 & $30.2 \%$ \\
\hline pass & 119 & $36.2 \%$ \\
\hline Very weak & 26 & $8.1 \%$ \\
\hline Total & 328 & $100 \%$ \\
\hline
\end{tabular}


Appendix (3)

List of Experts' Names who are specialized in Curricula, Teaching Methods and Psychology, Whom opinion was taken in research tests and lectures design ${ }^{(*)}$

\begin{tabular}{|l|l|l|}
\hline No. & Name & Job \\
\hline 1. & Zakia Ibrahim Kamel & $\begin{array}{l}\text { Emeritus Professor of Teaching Methods - Faculty of } \\
\text { Physical Education for Men - Alexandria University. }\end{array}$ \\
\hline 2. & Fatima Awad Saber & $\begin{array}{l}\text { Emeritus Professor of Teaching Methods - Faculty of } \\
\text { Physical Education for Men - Alexandria University. }\end{array}$ \\
\hline 3 & Mohsen Mohammed Darwish & $\begin{array}{l}\text { Emeritus Professor of Teaching Methods - Faculty of } \\
\text { Physical Education for Men - Alexandria University. }\end{array}$ \\
\hline 4. & Mervat Ali Khafajah & $\begin{array}{l}\text { Emeritus Professor of Teaching Methods - Faculty of } \\
\text { Physical Education for Men - Alexandria University. }\end{array}$ \\
\hline 5. & Heba Abdel Azim Imbabi & $\begin{array}{l}\text { Professor of Curricula - Faculty of Physical Education } \\
\text { for Men - Alexandria University. }\end{array}$ \\
\hline 6. & Magdi Hassan Yousef & $\begin{array}{l}\text { Professor of Sport Psychology - Faculty of Physical } \\
\text { Education for Men - Alexandria University. }\end{array}$ \\
\hline 7. & Sekina Mohamed Nasr Ismail & $\begin{array}{l}\text { Assistant Professor- Department of Physical } \\
\text { Education Principles - Faculty of Physical Education } \\
\text { for Men - Alexandria University }\end{array}$ \\
\hline
\end{tabular}


Alexandria University

Faculty of Physical Education for Men

Questionnaire about some Theoretical Contents of Six Thinking Hats' Lectures for Internal Field Practicum

Prof. Dr. /

\section{After greetings,}

The researchers are conducting a scientific study titled "The Six Thinking Hats and

Their Effect on Improving the Skill of Planning Lesson and attitudes of Students in Teaching Practicum"

The Six Thinking Hats are as the following:

1- White Hat (neutral thinking): it means giving accurate and real facts not associated with emotions. Teacher can use (lecture - discussion - questions and answers - survey) styles.

2- Red Hat (emotions and feelings):

It means thinking in terms of feelings where the teacher allows feelings exit

automatically from learners toward topics such as: I feel that it is a serious idea - he

always shows his feelings and emotions with or without reason - I feel that I will catch something - he is interested in feelings even if not supported by facts and information - I feel that the topic is very useful and successful.

3- Black Hat (negative thinking): it means searching for faults of any idea or existence of gaps in the topic (negative reason), followed by justification. Teacher allows learners to view the topic in a negative way, such as: pessimism and lack of optimism in success probabilities showing the defects and errors - always they criticize the performance - warn of consequences - focus on the obstacles and failed pessimism and be captive of it-criticize and make judgments.

4- Yellow Hat (optimistic thinking): means shining and concentrate on positive aspects of the topic, looking to the topic with positive views such as: optimism and hope - focuses on success probabilities and reduces failure risk- positives and benefits - construction supportive thinking - interested in opportunities and keen to exploit it

5- Green Hat (creative thinking):

He generates ideas and ask learners to produce as many new thoughts as possible using thinking methods such as brainstorming style, e.g.: Willing to take risks and consequences - keens about all new ideas, experiences and concepts - innovative and creative - always trying to develop and work to change - use creative phrases such as (what if, what, how, perhaps.)

6- Blue Hat (comprehensive thinking), is concerned with control, administration, guidance and give final judgment on the stuff, it is the implementation hat, learners are asked to develop plans for implementation in light of what has been taught in the previous hats from information, feelings, pros and cons, and suggestions, examples for this are : develop operational plans, make decisions - can see others' hats and respect it - consider all ideas of other hats - summarize general consensus and special results for the situation , and arranges his steps carefully

So, kindly please express your opinion about using the six thinking hats to teach Internal Field Practicum Course for second grade students, Faculty of Physical Education for Men Alexandria University, by placing your remarks about the form of using six thinking hats in teaching internal field training syllabus

This will effectively contributes in enrichment of this study.

All respect and sincere thanks for you

Questionnaire about lectures contents using six thinking hats 
(First week)

Time distribution of lectures time using Six Thinking Hats

\begin{tabular}{|l|l|l|l|l|l|l|}
\hline Week & day & date & grade & subject & unit & topics \\
\hline First & Saturday & March $16^{\text {th }}, 2014$ & second & Internal field training & $\begin{array}{l}\text { Educational } \\
\text { objectives }\end{array}$ & $\begin{array}{l}\text { - cognitive objectives } \\
\text {-psychomotor objectives } \\
\text {-emotional objectives }\end{array}$ \\
\hline
\end{tabular}

\begin{tabular}{|c|c|c|c|c|c|c|}
\hline \multirow[b]{2}{*}{ Time } & \multirow[b]{2}{*}{ Objectives } & \multirow[b]{2}{*}{$\begin{array}{l}\text { Six thinking hats } \\
\text { implementation steps }\end{array}$} & \multirow[b]{2}{*}{$\begin{array}{l}\text { Educational aids } \\
\text { and techniques }\end{array}$} & \multicolumn{3}{|c|}{$\begin{array}{c}\text { Your } \\
\text { Opinion }\end{array}$} \\
\hline & & & & Suitable & $\begin{array}{c}\text { Suitable } \\
\text { to some } \\
\text { extent }\end{array}$ & $\begin{array}{c}\text { Not } \\
\text { suitable }\end{array}$ \\
\hline $\begin{array}{l}10 \\
\text { minutes }\end{array}$ & $\begin{array}{l}\text { student has to } \\
\text { recognize } \\
\text { teaching } \\
\text { principles using } \\
\text { six thinking hats }\end{array}$ & \begin{tabular}{l}
\multicolumn{1}{c}{ Introduction } \\
Teacher gives a general \\
idea at beginning about \\
the six thinking hats and \\
distributes tasks for \\
teacher first and then \\
teaches the learner and \\
determines time periods \\
for each color of the six \\
hats
\end{tabular} & $\begin{array}{l}\text { Illustrative video of } \\
\text { six thinking hats and } \\
\text { their uses }\end{array}$ & & & \\
\hline $\begin{array}{l}25 \\
\text { minutes }\end{array}$ & $\begin{array}{l}\text { Teacher has to } \\
\text { introduce a new } \\
\text { topic to learners }\end{array}$ & $\begin{array}{l}\text { Phase I: White Hat } \\
\text { (neutral) thinking } \\
\text { - various types of } \\
\text { educational objectives } \\
\text { - objectives definition and } \\
\text { how they are measured } \\
\text { and observed } \\
\text { - Types of objectives } \\
\text { domains } \\
\text { - mentioning psychomotor } \\
\text { objectives categories } \\
\text { - Terms of drafting } \\
\text { behavioral objective. }\end{array}$ & $\begin{array}{l}\text { Visual presentation } \\
\text { of objective types, } \\
\text { drafting and its } \\
\text { categories in the } \\
\text { three domains. }\end{array}$ & & & \\
\hline $\begin{array}{l}5 \\
\text { minutes }\end{array}$ & $\begin{array}{l}\text { To allow student } \\
\text { to express his } \\
\text { feelings about } \\
\text { new ideas and } \\
\text { information }\end{array}$ & $\begin{array}{l}\text { Phase II: Red Hat } \\
\text { (emotions and feelings) } \\
\text { - I feel difficulty in } \\
\text { drafting specific } \\
\text { objectives } \\
\text { - The process of drafting } \\
\text { the emotional objectives is } \\
\text { difficult } \\
\text { - Skill's objective is the } \\
\text { most important } \\
\text { educational objective in } \\
\text { the lesson. }\end{array}$ & $\begin{array}{l}\text { Presentation of some } \\
\text { pictures which } \\
\text { express the red in } \\
\text { question }\end{array}$ & & & \\
\hline
\end{tabular}




\begin{tabular}{|c|c|c|c|c|c|c|}
\hline \multirow[b]{2}{*}{ Time } & \multirow[b]{2}{*}{ Objectives } & \multirow{2}{*}{$\begin{array}{l}\text { Six thinking hats } \\
\text { implementation steps }\end{array}$} & \multirow{2}{*}{$\begin{array}{l}\text { Educational aids } \\
\text { and techniques }\end{array}$} & \multicolumn{3}{|c|}{$\begin{array}{c}\text { Your } \\
\text { Opinion }\end{array}$} \\
\hline & & & & Suitable & $\begin{array}{c}\text { Suitable } \\
\text { to some } \\
\text { extent }\end{array}$ & $\begin{array}{c}\text { Not } \\
\text { suitable }\end{array}$ \\
\hline $\begin{array}{l}5 \\
\text { minutes }\end{array}$ & $\begin{array}{l}\text { student to } \\
\text { criticize the ideas } \\
\text { and topics that } \\
\text { were presented } \\
\text { indicating the } \\
\text { obstacles and } \\
\text { challenges }\end{array}$ & $\begin{array}{l}\text { Phase III: Black Hat } \\
\text { (negative thinking) } \\
\text { - I find it difficult to draft } \\
\text { the behavioral objective } \\
\text { which has no record level } \\
\text { - Many planned lesson } \\
\text { objectives may cause } \\
\text { forget each other } \\
\text { - Many planned lesson } \\
\text { objectives may cause } \\
\text { difficulty in achieving all } \\
\text { of it } \\
\text { - Expressing accurate } \\
\text { information is difficult to } \\
\text { define in knowledge } \\
\text { objective }\end{array}$ & $\begin{array}{l}\text { Present some } \\
\text { pictures which show } \\
\text { the negative } \\
\text { thinking and } \\
\text { learners criticism }\end{array}$ & & & \\
\hline $\begin{array}{l}5 \\
\text { minutes }\end{array}$ & $\begin{array}{l}\text { student Ali pros } \\
\text { that were } \\
\text { displayed in } \\
\text { themes }\end{array}$ & $\begin{array}{l}\text { Phase IV: Yellow Hat } \\
\text { (positive or optimistic } \\
\text { thinking) } \\
\text { - Appropriate wording of } \\
\text { emotional objective may } \\
\text { help students to feel happy } \\
\text { during the lesson } \\
\text { - concentrating on } \\
\text { emotional goal may help } \\
\text { students to achieve self- } \\
\text { confidence } \\
\text { - Good wording of } \\
\text { emotional goal may help } \\
\text { to uptake the practice of } \\
\text { physical education lessons } \\
\text { - concentrating on } \\
\text { physical objective is a } \\
\text { basis to gain skills } \\
\text { performance. } \\
\text { - Identifying and clarity } \\
\text { of the objective increases } \\
\text { lessons success chances } \\
\text { and reduces the } \\
\text { probability of failure. }\end{array}$ & $\begin{array}{l}\text { Present some } \\
\text { images and effects } \\
\text { which indicate } \\
\text { optimism }\end{array}$ & & & \\
\hline $\begin{array}{l}10 \\
\text { minutes }\end{array}$ & $\begin{array}{l}\text { Student has to } \\
\text { creates unusual } \\
\text { solutions to solve } \\
\text { some of the } \\
\text { obstacles and } \\
\text { problems that face } \\
\text { him during } \\
\text { learning. }\end{array}$ & $\begin{array}{l}\text { Phase } \mathbf{V} \text { :Green Hat } \\
\text { (creative thinking) } \\
\text { - What if information help } \\
\text { in mental visualization } \\
\text { - What information helps } \\
\text { to link the skill with other } \\
\text { skills } \\
\text { - What if information } \\
\text { help in exploring } \\
\text { movements which are } \\
\text { relevant to the skill } \\
\text { learned in the lesson } \\
\text { - Is the wording of } \\
\text { emotional object allows to } \\
\text { adjust student's emotional } \\
\text { behavior during } \\
\text { competition situations in } \\
\text { the lesson }\end{array}$ & $\begin{array}{l}\text { Present some } \\
\text { pictures and effects } \\
\text { which indicate } \\
\text { creativity and } \\
\text { innovation }\end{array}$ & & & \\
\hline
\end{tabular}




\begin{tabular}{|c|c|c|c|c|c|c|}
\hline \multirow[b]{2}{*}{ Time } & \multirow[b]{2}{*}{ Objectives } & \multirow[b]{2}{*}{$\begin{array}{l}\text { Six thinking hats } \\
\text { implementation steps }\end{array}$} & \multirow[b]{2}{*}{$\begin{array}{l}\text { Educational aids } \\
\text { and techniques }\end{array}$} & \multicolumn{3}{|c|}{$\begin{array}{c}\text { Your } \\
\text { Opinion }\end{array}$} \\
\hline & & & & Suitable & $\begin{array}{c}\text { Suitable } \\
\text { to some } \\
\text { extent }\end{array}$ & $\begin{array}{c}\text { Not } \\
\text { suitable }\end{array}$ \\
\hline $\begin{array}{l}20 \\
\text { minutes }\end{array}$ & $\begin{array}{l}\text { Student to be able } \\
\text { to set future plans } \\
\text { in light of what } \\
\text { has been } \\
\text { presented from } \\
\text { previous opinions } \\
\text { and to determine } \\
\text { procedural steps }\end{array}$ & $\begin{array}{l}\text { Phase VI: Blue Hat } \\
\text { (systematic or } \\
\text { comprehensive thinking) } \\
\text { - Physical objective only } \\
\text { include one or two fitness } \\
\text { elements } \\
\text { - Physical objective does } \\
\text { not cover all physical } \\
\text { elements used in the } \\
\text { lesson } \\
\text { - Objectives wording are } \\
\text { linked to specific } \\
\text { specifications in physical } \\
\text { education lessons } \\
\text { - Objectives which have } \\
\text { been set for the lesson } \\
\text { may suit a learning } \\
\text { environment in certain } \\
\text { circumstances and may } \\
\text { not suit another } \\
\text { environmental } \\
\text { circumstances }\end{array}$ & $\begin{array}{l}\text { Present some } \\
\text { pictures and effects } \\
\text { which indicate } \\
\text { setting procedural } \\
\text { plans and preparing } \\
\text { tools, aids, facilities } \\
\text { and multiple sources } \\
\text { for the academic } \\
\text { topic }\end{array}$ & & & \\
\hline $\begin{array}{l}10 \\
\text { minutes }\end{array}$ & & $\begin{array}{l}\text { final Phase: } \\
\text { Summarize the main ideas } \\
\text { of the topic studied using } \\
\text { Six Thinking hats and put } \\
\text { a new topic for reading for } \\
\text { next lecture. }\end{array}$ & $\begin{array}{l}\text { Present the new } \\
\text { topic title and main } \\
\text { ideas }\end{array}$ & & & \\
\hline
\end{tabular}

Questionnaire about lectures contents appropriateness with study weeks

\begin{tabular}{|l|l|l|c|c|}
\hline Weeks & lectures content & \multicolumn{3}{|c|}{ Your opinion } \\
\cline { 3 - 4 } & Suitable & $\begin{array}{c}\text { Suitable } \\
\text { to some } \\
\text { extent }\end{array}$ & $\begin{array}{c}\text { Not } \\
\text { suitable }\end{array}$ \\
\hline First week & Objectives & & & \\
\hline & Topics & & \\
\hline & $\begin{array}{l}\text { Lectures time } \\
\text { distribution }\end{array}$ & & & \\
\hline & $\begin{array}{l}\text { Implementation } \\
\text { steps }\end{array}$ & & & \\
\hline & $\begin{array}{l}\text { Educational tools } \\
\text { and techniques }\end{array}$ & & & \\
\hline
\end{tabular}




\section{Appendix (5)}

Alexandria University

Faculty of Physical Education for Men

Lesson Planning skill evaluation form for internal field training students

Prof. Dr. $/$

After greetings,

The researchers conducting a scientific study titled studying the theme of "The Six

Thinking Hats and Their Effect on Improving the Skill of Planning Lesson and attitudes of Students in Teaching Practicum"

Researchers are seeking your assistance by expressing your constructive comments about validity of phrases used in internal field training lesson planning evaluation scale for second grade students in Faculty of Physical Education for Men, Alexandria University, so please placing put $(\checkmark)$ mark in front of each phrase in the column that fit your opinion (suitable, suitable to some extent or not suitable).

All respect and sincere thanks for you

\section{Researchers}


Lesson planning skill evaluation form for internal field training students

\begin{tabular}{|c|c|c|c|c|}
\hline \multirow[b]{2}{*}{ No. } & \multirow[b]{2}{*}{ Phrase } & \multicolumn{3}{|c|}{ Your opinion } \\
\hline & & Suitable & $\begin{array}{c}\text { Suitable } \\
\text { to some } \\
\text { extent }\end{array}$ & $\begin{array}{l}\text { Not } \\
\text { suitable }\end{array}$ \\
\hline 1. & $\begin{array}{l}\text { He knows Physical Education objectives in educational } \\
\text { phases. }\end{array}$ & & & \\
\hline 2. & $\begin{array}{l}\text { He plans lessons according procedural programs in various } \\
\text { education stages. }\end{array}$ & & & \\
\hline 3 & He is aware of educational environment and its components & & & \\
\hline 4. & He writes school grade data (day - date - lesson time). & & & \\
\hline 5. & He prepares the lesson in a manner includes main parts & & & \\
\hline 6. & He clearly determines Lesson objectives. & & & \\
\hline 7. & $\begin{array}{l}\text { He drives lesson objective from studied educational unit' } \\
\text { objectives. }\end{array}$ & & & \\
\hline 8. & $\begin{array}{l}\text { He identifies behavioral objectives in a manner allow } \\
\text { observation and measurement. }\end{array}$ & & & \\
\hline 9. & $\begin{array}{l}\text { Objectives include the three aspects of learning (cognitive - } \\
\text { emotional - psychomotor). }\end{array}$ & & & \\
\hline 10. & Set standards for desired objectives. & & & \\
\hline 11. & Objectives commensurate with available facilities. & & & \\
\hline 12. & Objectives commensurate with time allocated to the lesson & & & \\
\hline 13. & $\begin{array}{l}\text { He determines teaching methods and styles that are } \\
\text { appropriate to learners' abilities to achieve lesson's objectives. }\end{array}$ & & & \\
\hline 14. & $\begin{array}{l}\text { He chooses scientific content in a manner that allows } \\
\text { achieving lesson objectives. }\end{array}$ & & & \\
\hline 15. & $\begin{array}{l}\text { He defines educational tools and aids that allow implementing } \\
\text { lesson activities. }\end{array}$ & & & \\
\hline 16. & He uses illustrations and shapes in lesson preparation. & & & \\
\hline 17. & He must assure that writing is in a proper scientific manner. & & & \\
\hline 18. & $\begin{array}{l}\text { Scientific content of any part communicates with other lesson } \\
\text { parts }\end{array}$ & & & \\
\hline 19. & $\begin{array}{l}\text { Diversify in activities used within the lesson to consider } \\
\text { learners' individual differences. }\end{array}$ & & & \\
\hline 20. & He defines evaluation methods and tools in lesson planning. & & & \\
\hline 21. & $\begin{array}{l}\text { He plans alternatives in case of emergency conditions like } \\
\text { weather change or external factors. }\end{array}$ & & & \\
\hline 22. & $\begin{array}{l}\text { He gets assistance from scientific references in lesson } \\
\text { preparation. }\end{array}$ & & & \\
\hline 23. & He collects scientific content from specialized sources . & & & \\
\hline
\end{tabular}


Appendix (6)

Alexandria University

Faculty of Physical Education for Men

Questionnaire or second grade students

\section{Faculty of physical education for men- Alexandria University}

Dear student teacher

This questionnaire is aimed at collecting data and information that help to know your personal opinion in using the educational program using Six Thinking Hats to develop your emotional aspects in internal field training course.

* Your sincere cooperation with accurate answers will help achieve research objectives.

* Answer instructions:

There is a set of phrases in front of each three columns under titles (Yes, to some extent, No) We hope that you determine your response degree by checking $(\checkmark)$ in the cell which reflect what you think about using the educational program for developing your emotional aspects of internal field training course. ,

* Note: Do not leave a phrase without answer

Thanks for your cooperation,

\section{Researchers}




\begin{tabular}{|c|c|c|c|c|}
\hline No & phrases & Yes & $\begin{array}{c}\text { to } \\
\text { some } \\
\text { extent }\end{array}$ & No \\
\hline & $\begin{array}{l}\text { Does the proposed educational program using Six Thinking Hats equip } \\
\text { you with the following: }\end{array}$ & & & \\
\hline & I: Trends: & & & \\
\hline & The proposed educational program makes the student able to: & & & \\
\hline 1. & $\begin{array}{l}\text { Wish to learn Internal Field Training Course content using the Six } \\
\text { Thinking Hats using the program prepared for that. }\end{array}$ & & & " \\
\hline 2. & $\begin{array}{l}\text { Interested in learning lesson planning skill using six thinking hats to } \\
\text { improve performance }\end{array}$ & & & \\
\hline 3 & $\begin{array}{l}\text { Feel satisfied when learns lesson planning skill using Six Thinking } \\
\text { Hats. }\end{array}$ & & & \\
\hline 4. & $\begin{array}{l}\text { Freely determine method of learning lesson planning skill using Six } \\
\text { Thinking Hats. }\end{array}$ & & & \\
\hline 5. & $\begin{array}{l}\text { feel that learning lesson planning skill using six thinking hats is waste } \\
\text { of time and effort }\end{array}$ & & & \\
\hline 6. & $\begin{array}{l}\text { Self-dependent when learns lesson planning skill using Six Thinking } \\
\text { Hats. }\end{array}$ & & & \\
\hline 7. & $\begin{array}{l}\text { Feel that learning by using Six Thinking Hats more fun than other } \\
\text { teaching methods . }\end{array}$ & & & \\
\hline 8. & $\begin{array}{l}\text { Fear of failure when learning lesson planning skill using the Six } \\
\text { Thinking Hats }\end{array}$ & & & \\
\hline 9. & $\begin{array}{l}\text { Feel that learning lesson planning skill using the Six Thinking Hats } \\
\text { reduces concentration. }\end{array}$ & & & \\
\hline 10. & $\begin{array}{l}\text { Feel that learning lesson planning skill using six thinking hats reduces } \\
\text { the interaction between learners and teacher. }\end{array}$ & & & \\
\hline 11. & $\begin{array}{l}\text { Prefer to get knowledge about lesson planning skill from six thinking } \\
\text { hats program instead of syllabus book. }\end{array}$ & & & \\
\hline 12. & $\begin{array}{l}\text { Respond to educational points given by teacher using Six Thinking } \\
\text { Hats }\end{array}$ & & & \\
\hline 13. & Feel that using Six Thinking Hats help dialogue with colleagues & & & \\
\hline 14. & Feel safe when learning lesson planning skill using six thinking hats. & & & \\
\hline 15. & Acquires logical thinking way using Six Thinking Hats . & & & \\
\hline 16. & Hate learning lesson planning skill using Six Thinking Hats skill. & & & \\
\hline \multirow[t]{3}{*}{17.} & $\begin{array}{l}\text { wish to present some educational videos using six thinking hats about } \\
\text { physical education lesson planning), }\end{array}$ & & & \\
\hline & Second: tendencies & & & \\
\hline & The proposed educational program makes the student able to: & & & \\
\hline 18. & Always acquaintance with the new about lesson planning models & & & \\
\hline 19. & $\begin{array}{l}\text { Participate in training courses organized by specialist bodies in } \\
\text { internal field training. }\end{array}$ & & & \\
\hline 20. & $\begin{array}{l}\text { Care to practice plan types for physical education lessons and enjoy } \\
\text { with it in leisure time. }\end{array}$ & & & \\
\hline 21. & $\begin{array}{l}\text { Have desire to follow good planning models in other Arab and } \\
\text { European countries. }\end{array}$ & & & \\
\hline 22. & $\begin{array}{l}\text { feel non concentration or interest when learn lesson planning using six } \\
\text { thinking hats }\end{array}$ & & & \\
\hline 23. & $\begin{array}{l}\text { Feel that using Six Thinking Hats motivate to learn lesson planning } \\
\text { skill }\end{array}$ & & & \\
\hline
\end{tabular}




\begin{tabular}{|c|c|c|c|c|}
\hline No & phrases & Yes & $\begin{array}{c}\text { to } \\
\text { some } \\
\text { extent }\end{array}$ & No \\
\hline & Third: commitment to professional ethics in word and deed: & & & \\
\hline & The proposed educational program makes student able to: & & & \\
\hline 24. & $\begin{array}{l}\text { Prefer learning lesson planning skill using the Six Thinking Hats to } \\
\text { help him to self-control inside and outside the lectures. }\end{array}$ & & & \\
\hline 25. & $\begin{array}{l}\text { feels that learning lesson planning using six thinking hats develop my } \\
\text { leadership skill in theoretical and practical teaching situations }\end{array}$ & & & \\
\hline 26. & $\begin{array}{l}\text { Show courage when submitting kinetic model for learners in internal } \\
\text { field training based on pre-planning using Six Thinking Hats . }\end{array}$ & & & \\
\hline 27. & $\begin{array}{l}\text { Organize teaching situation in planning to achieve the desired } \\
\text { objective in internal field training. }\end{array}$ & & & \\
\hline 28. & $\begin{array}{l}\text { Consider honest in acquiring knowledge and information while } \\
\text { planning physical education lessons for learners in internal field } \\
\text { training }\end{array}$ & & & \\
\hline 29. & $\begin{array}{l}\text { Earn honesty in determining actual learners level based on good } \\
\text { planning for internal field training lessons. }\end{array}$ & & & \\
\hline 30. & $\begin{array}{l}\text { Participate with the group in learn lesson planning in general using Six } \\
\text { Thinking Hats . }\end{array}$ & & & \\
\hline
\end{tabular}


Appendix (7)

Frequency, percentage and relative importance of experts opinion about lesson planning skill observation card $(n=7)$

\begin{tabular}{|c|c|c|c|c|c|c|c|c|}
\hline & \multirow[t]{2}{*}{ Phrases } & \multicolumn{2}{|c|}{ Suitable } & \multicolumn{2}{|c|}{$\begin{array}{c}\text { Suitable to } \\
\text { some extent }\end{array}$} & \multicolumn{2}{|c|}{ Not suitable } & \multirow{2}{*}{$\begin{array}{l}\text { Relative } \\
\text { Importance }\end{array}$} \\
\hline & & Freq. & $\%$ & Freq. & $\%$ & Freq. & $\%$ & \\
\hline 1. & $\begin{array}{l}\text { He knows Physical Education objectives in educational } \\
\text { phases. }\end{array}$ & 7 & $100 \%$ & 0 & $0 \%$ & 0 & $0 \%$ & $100 \%$ \\
\hline 2. & $\begin{array}{l}\text { He plans lessons according procedural programs in } \\
\text { various education stages. }\end{array}$ & 7 & $100 \%$ & 0 & $0 \%$ & 0 & $0 \%$ & $100 \%$ \\
\hline 3 & $\begin{array}{l}\text { He is aware of educational environment and its } \\
\text { components. }\end{array}$ & 7 & $100 \%$ & 0 & $0 \%$ & 0 & $0 \%$ & $100 \%$ \\
\hline 4. & He writes school grade data (day - date - lesson time). & 7 & $100 \%$ & 0 & $0 \%$ & 0 & $0 \%$ & $100 \%$ \\
\hline 5. & He prepares the lesson in a manner includes main parts. & 7 & $100 \%$ & 0 & $0 \%$ & 0 & $0 \%$ & $100 \%$ \\
\hline 6. & He clearly determines Lesson objectives. & 7 & $100 \%$ & 0 & $0 \%$ & 0 & $0 \%$ & $100 \%$ \\
\hline 7. & $\begin{array}{l}\text { He drives lesson objective from studied educational unit' } \\
\text { objectives. }\end{array}$ & 7 & $100 \%$ & 0 & $0 \%$ & 0 & $0 \%$ & $100 \%$ \\
\hline 8. & $\begin{array}{l}\text { He specifies behavioral objectives in a manner allow } \\
\text { observation and measurement. }\end{array}$ & 7 & $100 \%$ & 0 & $0 \%$ & 0 & $0 \%$ & $100 \%$ \\
\hline 9. & $\begin{array}{l}\text { Objectives include the three aspects of learning } \\
\text { (cognitive - emotional - psychomotor). }\end{array}$ & 7 & $100 \%$ & 0 & $0 \%$ & 0 & $0 \%$ & $100 \%$ \\
\hline 10. & Word objective in a manner suit learners maturity & 0 & $0 \%$ & 0 & $0 \%$ & 7 & $100 \%$ & $\% 0$ \\
\hline 11. & Set standards for desired objectives. & 7 & $100 \%$ & 0 & $0 \%$ & 0 & $0 \%$ & $100 \%$ \\
\hline 12. & Objectives commensurate with available facilities. & 7 & $100 \%$ & 0 & $0 \%$ & 0 & $0 \%$ & $100 \%$ \\
\hline 13. & $\begin{array}{l}\text { Objectives commensurate with time allocated to the } \\
\text { lesson }\end{array}$ & 7 & $100 \%$ & 0 & $0 \%$ & 0 & $0 \%$ & $100 \%$ \\
\hline 14. & $\begin{array}{l}\text { Determines teaching methods and styles that are } \\
\text { appropriate to learners abilities to achieve lesson's } \\
\text { objectives. }\end{array}$ & 7 & $100 \%$ & 0 & $0 \%$ & 0 & $0 \%$ & $100 \%$ \\
\hline 15. & $\begin{array}{l}\text { Choose scientific content in a manner that allows } \\
\text { achieving lesson objectives. }\end{array}$ & 7 & $100 \%$ & 0 & $0 \%$ & 0 & $0 \%$ & $100 \%$ \\
\hline 16. & $\begin{array}{l}\text { Define educational tools and aids that allow } \\
\text { implementing lesson activities. }\end{array}$ & 7 & $100 \%$ & 0 & $0 \%$ & 0 & $0 \%$ & $100 \%$ \\
\hline 17. & Use illustrations and shapes in lesson preparation. & 7 & $100 \%$ & 0 & $0 \%$ & 0 & $0 \%$ & $100 \%$ \\
\hline 18. & Writing exercises in proper scientific manner. & 7 & $100 \%$ & 0 & $0 \%$ & 0 & $0 \%$ & $100 \%$ \\
\hline 19. & Arrange lesson contents and parts in related manner & 7 & $100 \%$ & 0 & $0 \%$ & 0 & $0 \%$ & $100 \%$ \\
\hline 20. & Consider good preparation bases and principles & 0 & $\% 0$ & 0 & $0 \%$ & 7 & $100 \%$ & $\% 0$ \\
\hline 21. & $\begin{array}{l}\text { Scientific content of any part communicate with other } \\
\text { lesson parts }\end{array}$ & 7 & $100 \%$ & 0 & $0 \%$ & 0 & $0 \%$ & $100 \%$ \\
\hline 22. & $\begin{array}{l}\text { Diversify in activities used within the lesson to consider } \\
\text { learners' individual differences. }\end{array}$ & 7 & $100 \%$ & 0 & $0 \%$ & 0 & $0 \%$ & $100 \%$ \\
\hline 23. & Defines evaluation methods and tools in lesson planning. & 7 & $100 \%$ & 0 & $0 \%$ & 0 & $0 \%$ & $100 \%$ \\
\hline 24 & $\begin{array}{l}\text { Plan alternatives in case of emergency conditions like } \\
\text { weather change or external factors. }\end{array}$ & 7 & $100 \%$ & 0 & $0 \%$ & 0 & $0 \%$ & $100 \%$ \\
\hline 25 & Plan lessons in emergency cases & 0 & $0 \%$ & 0 & $0 \%$ & 7 & $100 \%$ & $\% 0$ \\
\hline 26 & $\begin{array}{l}\text { Get assistance from scientific references in lesson } \\
\text { preparation. }\end{array}$ & 7 & $100 \%$ & 0 & $0 \%$ & 0 & $0 \%$ & $100 \%$ \\
\hline 27 & Collect scientific content from specialized sources & 7 & $100 \%$ & 0 & $0 \%$ & 0 & $0 \%$ & $100 \%$ \\
\hline 28 & Prepare lesson from familier skills & 0 & $0 \%$ & 0 & $0 \%$ & 7 & $100 \%$ & $\% 0$ \\
\hline
\end{tabular}

It is clear from the above table that relative percentage for all phrases were $100 \%$ except for phrases $(10,20,25,28)$ which have been removed as researcher adopt $100 \%$ approval percentage to accept phrases 


\section{Internal consistency coefficient:}

\section{Table (1) internal consistency coefficient (Phrase correlation with its aspect total) and Cronbach alpha for Lesson planning skill evaluation form $(\mathbf{n}=23)$}

\begin{tabular}{|c|c|c|c|}
\hline No & Phrase & $\begin{array}{l}\text { Cronbach } \\
\text { Alpha } \\
\text { if phrase } \\
\text { removed }\end{array}$ & $\begin{array}{l}\text { Cronbach } \\
\text { Alpha }\end{array}$ \\
\hline 1. & He knows Physical Education objectives in educational phases. & 0.828 & \multirow{23}{*}{$0.826 *$} \\
\hline 2. & He plans lessons according procedural programs in various education stages. & 0.822 & \\
\hline 3 & He is aware of educational environment and its components. & 0.811 & \\
\hline 4. & He writes school grade data (day - date - lesson time). & 0.821 & \\
\hline 5. & He prepares the lesson in a manner includes main parts. & 0.814 & \\
\hline 6. & He clearly determines Lesson objectives. & 0.818 & \\
\hline 7. & He drives lesson objective from studied educational unit' objectives. & 0.809 & \\
\hline 8. & $\begin{array}{l}\text { He specifies behavioral objectives in a manner allow observation and } \\
\text { measurement. }\end{array}$ & 0.817 & \\
\hline 9. & $\begin{array}{l}\text { Objectives include the three aspects of learning (cognitive - emotional - } \\
\text { psychomotor). }\end{array}$ & 0.809 & \\
\hline 10. & He sets standards for desired objectives. & 0.808 & \\
\hline 11. & Objectives commensurate with available facilities. & 0.826 & \\
\hline 12. & Objectives commensurate with time allocated to the lesson & 0.820 & \\
\hline 13. & $\begin{array}{l}\text { He determines teaching methods and styles that are appropriate to learners } \\
\text { abilities to achieve lesson's objectives . }\end{array}$ & 0.823 & \\
\hline 14. & $\begin{array}{l}\text { He chooses scientific content in a manner that allows achieving lesson } \\
\text { objectives. }\end{array}$ & 0.826 & \\
\hline 15. & $\begin{array}{l}\text { He defines educational tools and aids that allow implementing lesson } \\
\text { activities. }\end{array}$ & 0.828 & \\
\hline 16. & He uses illustrations and shapes in lesson preparation. & 0.820 & \\
\hline 17. & He writes exercises in proper scientific manner. & 0.811 & \\
\hline 18. & He arranges lesson contents and parts in related manner & 0.822 & \\
\hline 19. & He specifies content of any part communicate with other lesson parts & 0.834 & \\
\hline 20. & $\begin{array}{l}\text { Diversify in activities used within the lesson to consider learners' individual } \\
\text { differences. }\end{array}$ & 0.825 & \\
\hline 21. & He defines evaluation methods and tools in lesson planning. & 0.808 & \\
\hline 22. & $\begin{array}{l}\text { He plans alternatives in case of emergency conditions like weather change } \\
\text { or external factors. }\end{array}$ & 0.813 & \\
\hline 23. & He gets assistance from scientific references in lesson preparation. & 0.830 & \\
\hline 24 & He collects scientific content from specialized sources . & 0.828 & \\
\hline
\end{tabular}

Significant at 0.05 level $=0.404$

Significant at 0.05 level $=0.515$

Table (1) results reveal that internal consistency coefficient ranged between $(0.808$ and 0.834 ) which is significant at 0.05 level. This confirms that phrases are valid, belongs to its aspect, and measures what the aspect measures. Cronbach alpha coefficient value valued to (0.826), and this value is considered a strong evidence of homogeneity of aspect phrases and that all phrases contribute in aspect buildings and any deletion or addition for any phrase will affects negatively on aspect building. 
Internal consistency coefficient:

Table (1)
Internal consistency coefficient (Phrase correlation with its aspect total) and Cronbach alpha for attitudes scale $(n=14)$

Aspect I - Trends

\begin{tabular}{|c|c|c|c|}
\hline No & Phrase & $\begin{array}{l}\text { Cronbach } \\
\text { Alpha } \\
\text { if phrase } \\
\text { removed }\end{array}$ & $\begin{array}{l}\text { Cronbach } \\
\text { Alpha }\end{array}$ \\
\hline \multicolumn{3}{|c|}{ Aspect I trend } & \multirow{18}{*}{0.899} \\
\hline 1. & $\begin{array}{l}\text { He wishes to learn internal field training course content using the Six Thinking Hats } \\
\text { using the program prepared for that. }\end{array}$ & 0.894 & \\
\hline 2. & $\begin{array}{l}\text { He is interested in learning lesson planning skill using six thinking hats to improve } \\
\text { performance }\end{array}$ & 0.889 & \\
\hline 3 & He feels satisfied when learns lesson planning skill using Six Thinking Hats. & 0.888 & \\
\hline 4. & He freely determines method of learning lesson planning skill using Six Thinking Hats. & 0.891 & \\
\hline 5. & $\begin{array}{l}\text { He feels that learning lesson planning skill using six thinking hats is waste of time and } \\
\text { effort }\end{array}$ & 0.889 & \\
\hline 6. & He is self-dependent when learns lesson planning skill using Six Thinking Hats. & 0.891 & \\
\hline 7. & $\begin{array}{l}\text { He Feel that learning by using Six Thinking Hats more fun than other teaching } \\
\text { methods. }\end{array}$ & 0.892 & \\
\hline 8. & He fears of failure when learning lesson planning skill using the Six Thinking Hats & 0.894 & \\
\hline 9. & $\begin{array}{l}\text { He feels that learning lesson planning skill using the Six Thinking Hats reduces } \\
\text { concentration. }\end{array}$ & 0.894 & \\
\hline 10. & $\begin{array}{l}\text { He feels that learning lesson planning skill using six thinking hats reduces the } \\
\text { interaction between learners and teacher. }\end{array}$ & 0.903 & \\
\hline 11. & $\begin{array}{l}\text { He prefers to get knowledge about lesson planning skill from six thinking hats program } \\
\text { instead of syllabus book. }\end{array}$ & 0.893 & \\
\hline 12. & He responds to educational points given by teacher using Six Thinking Hats & 0.896 & \\
\hline 13. & He feels that using Six Thinking Hats help dialogue with colleagues & 0.891 & \\
\hline 14. & He feels safe when learning lesson planning skill using six thinking hats. & 0.889 & \\
\hline 15. & He acquires logical thinking way using Six Thinking Hats. & 0.889 & \\
\hline 16. & He Hates learning lesson planning skill using Six Thinking Hats skill. & 0.912 & \\
\hline 17. & $\begin{array}{l}\text { He wishes to present some educational videos using six thinking hats about physical } \\
\text { education lesson planning), }\end{array}$ & 0.885 & \\
\hline
\end{tabular}

Significant at 0.05 level $=0.514$

Significant at 0.05 level $=0.641$

Table (1) results show that the internal consistency coefficient ranged between $(0.885$ and 0.912 ) which is significant at 0.05 level. This confirms that phrases are valid, belongs to its aspect, and measures what the aspect measures. Cronbach alpha coefficient's value valued to (0.899), and this value is considered a strong evidence of homogeneity of aspect phrases and that all phrases contribute in aspect buildings and any deletion or addition for any phrase will affects negatively on aspect building. 
Table (2)

internal consistency coefficient (Phrase correlation with its aspect total) and Cronbach alpha for attitudes scale $(n=14)$

Aspect II - Tendencies

\begin{tabular}{|c|c|c|c|}
\hline No & Phrase & $\begin{array}{c}\text { Cronbach } \\
\text { Alpha } \\
\text { if phrase } \\
\text { removed }\end{array}$ & $\begin{array}{c}\text { Cronbach } \\
\text { Alpha }\end{array}$ \\
\hline \multicolumn{3}{|c|}{ Aspect II - Tendencies } & \multirow{7}{*}{0.598} \\
\hline 18 & He always acquaintances with the new about lesson planning models & 0.743 & \\
\hline 19 & $\begin{array}{l}\text { He participates in training courses organized by specialist bodies in } \\
\text { internal field training. }\end{array}$ & 0.499 & \\
\hline 20 & $\begin{array}{l}\text { He cares to practice plan types for physical education lessons and enjoy } \\
\text { with it in leisure time. }\end{array}$ & 0.542 & \\
\hline 21 & $\begin{array}{l}\text { He has a desire to follow good planning models in other Arab and } \\
\text { European countries. }\end{array}$ & 0.547 & \\
\hline 22 & $\begin{array}{l}\text { He feels non concentration or interest when learn lesson planning using } \\
\text { six thinking hats }\end{array}$ & 0.456 & \\
\hline 23 & $\begin{array}{l}\text { He feels that using Six Thinking Hats motivate to learn lesson planning } \\
\text { skill }\end{array}$ & 0.452 & \\
\hline
\end{tabular}

Table (2) results show that the internal consistency coefficient ranged between $(0.452$ and 0.743 ) which is significant at 0.05 level. This confirms that phrases are valid, belong to its aspect, and measure what the aspect measure. Cronbach alpha coefficient's value valued to (0.598), and this value is considered a strong evidence of homogeneity of aspect phrases and that all phrases contribute in aspect buildings and any deletion or addition for any phrase will affects negatively on aspect building. 
Table (3)

internal consistency coefficient (Phrase correlation with its aspect total) and Cronbach alpha for attitudes scale $(n=14)$

Aspect III - commitment to professional ethics in word and deed

\begin{tabular}{l||l|c||c||}
\hline \hline No & \multicolumn{1}{|c||}{ Phrase } & $\begin{array}{c}\text { Cronbach } \\
\text { Alpha } \\
\text { if phrase } \\
\text { removed }\end{array}$ & $\begin{array}{c}\text { Cronbach } \\
\text { Alpha }\end{array}$ \\
\hline \hline Aspect III - commitment to professional ethics in word and deed & \multicolumn{1}{|c||}{} \\
\hline 24. & $\begin{array}{l}\text { He prefers learning lesson planning skill using the Six Thinking Hats to help } \\
\text { him to self-control inside and outside the lectures. }\end{array}$ & 0.806 \\
\hline 25. & $\begin{array}{l}\text { He feels that learning lesson planning using six thinking hats develop my } \\
\text { leadership skill in theoretical and practical teaching situations }\end{array}$ & 0.624 \\
\hline 26. & $\begin{array}{l}\text { He shows courage when submitting kinetic model for learners in internal field } \\
\text { training based on pre-planning using Six Thinking Hats. }\end{array}$ & 0.500 \\
\hline 27. & $\begin{array}{l}\text { He organizes teaching situation in planning to achieve the desired objective in } \\
\text { internal field training. }\end{array}$ & 0.602 \\
\hline 28. & $\begin{array}{l}\text { He is honest in acquiring knowledge and information while planning physical } \\
\text { education lessons for learners in internal field training }\end{array}$ & 0.606 \\
\hline 29. & $\begin{array}{l}\text { He earns honesty in determining actual learners' level based on good } \\
\text { planning for internal field training lessons. }\end{array}$ & 0.650 \\
\hline 30. & $\begin{array}{l}\text { He participates with the group in learn lesson planning in general using Six } \\
\text { Thinking Hats. }\end{array}$ & 0.537 \\
\hline \hline
\end{tabular}

Table (3) results show that internal consistency coefficient ranged between $(0.500$ and 0.806 ) which is significant at 0.05 level. This confirm that phrases are valid, belong to its aspect, and measure what the aspect measure. Cronbach alpha coefficient's value valued to (0.650), and this value is considered a strong evidence of homogeneity of aspect phrases and that all phrases contribute in aspect buildings and any deletion or addition for any phrase will affects negatively on aspect building. 
Appendix (10)

Frequency, percentage and relative importance of experts opinion in lectures design based on six thinking hats strategy $(n=7)$

\begin{tabular}{|c|c|c|c|c|c|c|c|c|}
\hline \multirow[t]{2}{*}{ No } & \multirow[t]{2}{*}{ Phrases } & \multicolumn{2}{|c|}{ Suitable } & \multicolumn{2}{|c|}{$\begin{array}{c}\text { Suitable to } \\
\text { Some } \\
\text { extent }\end{array}$} & \multicolumn{2}{|c|}{ Not suitable } & \multirow[t]{2}{*}{$\begin{array}{c}\text { Relative } \\
\text { Importance }\end{array}$} \\
\hline & & Freq. & $\%$ & Freq. & $\%$ & Freq. & $\%$ & \\
\hline 1. & $\begin{array}{l}\text { Introduction } \\
\text { Teacher gives a general idea at beginning of the } \\
\text { lecture on 'What is the six thinking hats and distribute } \\
\text { tasks for teacher first and then teach the learner and } \\
\text { determine time periods for each color of the six hats }\end{array}$ & 7 & $100 \%$ & $\mathbf{0}$ & $0 \%$ & $\mathbf{0}$ & $0 \%$ & $100 \%$ \\
\hline 2. & $\begin{array}{l}\text { Phase I: White Hat (neutral) thinking } \\
\text { - various types educational objectives } \\
\text { - objectives definition and how they are measured and } \\
\text { observed } \\
\text { - Types of objectives domains } \\
\text { - mention psychomotor objectives categories } \\
\text { - terms of drafting behavioral objective. }\end{array}$ & 7 & $100 \%$ & $\mathbf{0}$ & $0 \%$ & $\mathbf{0}$ & $0 \%$ & $100 \%$ \\
\hline 3 & $\begin{array}{l}\text { Phase II: Red Hat (emotions and feelings) } \\
\text { - I feel difficulty in drafting specific objectives } \\
\text { - The process of drafting emotional objectives is } \\
\text { difficult } \\
\text { - Skill objective is the most important educational } \\
\text { objective in the lesson. }\end{array}$ & 7 & $100 \%$ & $\mathbf{0}$ & $0 \%$ & $\mathbf{0}$ & $0 \%$ & $100 \%$ \\
\hline 4. & $\begin{array}{l}\text { Phase III: Black Hat (negative thinking) } \\
\text { - I find it difficult to draft the behavioral objective } \\
\text { which has no record level } \\
\text { - Many planned lesson objectives may cause forget } \\
\text { each other } \\
\text { - Many planned lesson objectives may cause difficulty } \\
\text { in achieving all of it } \\
\text { - Expressing accurate information is difficult to define } \\
\text { in knowledge objective }\end{array}$ & 7 & $100 \%$ & 0 & $0 \%$ & 0 & $0 \%$ & $100 \%$ \\
\hline 5. & $\begin{array}{l}\text { Phase IV: Yellow Hat (positive or optimistic thinking) } \\
\text { - Appropriate wording of emotional objective may } \\
\text { help students to feel happy during the lesson } \\
\text { - concentrating on emotional goal may help students } \\
\text { to achieve self-confidence } \\
\text { - Good wording of emotional goal may help to uptake } \\
\text { the practice of physical education lessons } \\
\text { - concentrating on physical objective is a basis to gain } \\
\text { skills performance. } \\
\text { - Identifying and clarity of the objective increases } \\
\text { lessons success chances and reduces the probability of } \\
\text { failure. }\end{array}$ & 7 & $100 \%$ & 0 & $0 \%$ & $\mathbf{0}$ & $0 \%$ & $100 \%$ \\
\hline 6. & $\begin{array}{l}\text { Phase V :Green Hat (creative thinking) } \\
\text { - What if information help in mental visualization } \\
\text { - What information helps to link the skill with other } \\
\text { skills } \\
\text { - What if information help in exploring movements } \\
\text { which are relevant to the skill learned in the lesson } \\
\text { - Is the wording of emotional object allows to adjust } \\
\text { student's emotional behavior during competition } \\
\text { situations in the lesson }\end{array}$ & 7 & $100 \%$ & $\mathbf{0}$ & $0 \%$ & $\mathbf{0}$ & $0 \%$ & $100 \%$ \\
\hline 7. & $\begin{array}{l}\text { Phase VI: Blue Hat (systematic or comprehensive } \\
\text { thinking) } \\
\text { - Physical objective only include one or two fitness } \\
\text { elements } \\
\text { - Physical objective does not cover all physical } \\
\text { elements used in the lesson } \\
\text { - Objectives wording are linked to specific } \\
\text { specifications in physical education lessons } \\
\text { - Objectives which have been set for the lesson may } \\
\text { suit a learning environment in certain circumstances } \\
\text { and may not suit another environmental } \\
\text { circumstances }\end{array}$ & 7 & $100 \%$ & $\mathbf{0}$ & $0 \%$ & $\mathbf{0}$ & $0 \%$ & $100 \%$ \\
\hline
\end{tabular}




\begin{tabular}{|c|c|c|c|c|c|c|c|c|}
\hline \multirow[t]{2}{*}{ No } & \multirow[t]{2}{*}{$\overline{\text { Phrases }}$} & \multicolumn{2}{|c|}{ Suitable } & \multicolumn{2}{|c|}{$\begin{array}{c}\text { Suitable to } \\
\text { Some } \\
\text { extent }\end{array}$} & \multicolumn{2}{|c|}{ Not suitable } & \multirow[t]{2}{*}{$\begin{array}{c}\text { Relative } \\
\text { Importance }\end{array}$} \\
\hline & & Freq. & $\%$ & Freq. & $\%$ & Freq. & $\%$ & \\
\hline$\overline{8 .}$ & $\begin{array}{l}\text { final Phase: } \\
\text { Summarize the main ideas of the topic studied using } \\
\text { Six Thinking hats and put a new topic for reading for } \\
\text { next lecture. }\end{array}$ & 7 & $100 \%$ & $\mathbf{0}$ & $0 \%$ & $\mathbf{0}$ & $\mathbf{0 \%}$ & $100 \%$ \\
\hline 9. & Objectives & 7 & $100 \%$ & $\mathbf{0}$ & $0 \%$ & $\mathbf{0}$ & $\mathbf{0 \%}$ & $100 \%$ \\
\hline 10. & Topics & 7 & $100 \%$ & $\mathbf{0}$ & 0\% & $\mathbf{0}$ & $\mathbf{0 \%}$ & $100 \%$ \\
\hline 11. & Lectures time distribution & 7 & $100 \%$ & $\mathbf{0}$ & $\mathbf{0 \%}$ & $\mathbf{0}$ & $\mathbf{0 \%}$ & $100 \%$ \\
\hline 12. & Implementation steps & 7 & $100 \%$ & $\mathbf{0}$ & $0 \%$ & $\mathbf{0}$ & $\mathbf{0 \%}$ & $100 \%$ \\
\hline 13. & Educational tools and techniques & 7 & $100 \%$ & $\mathbf{0}$ & $0 \%$ & $\mathbf{0}$ & 0\% & $100 \%$ \\
\hline
\end{tabular}

